\title{
Amide-Directed Formation of Five-Coordinate Osmium Alkylidenes from Alkynes
}

\author{
Noelia Casanova, ${ }^{\dagger}$ Miguel A. Esteruelas, ${ }^{*}, \dot{\dagger}$ Moisés Gulías, ${ }^{\dagger}$ Carmen Larramona, ${ }^{\dagger}$ José L. Mascareñas, ${ }^{*}, \dagger$ \\ and Enrique Oñate
}

†Centro Singular de Investigación en Química Biolóxica e Materiais Moleculares (CIQUS) and Departamento de Química Orgánica, Universidade de Santiago de Compostela, Jenaro de la Fuente, 15782 Santiago de Compostela, Spain

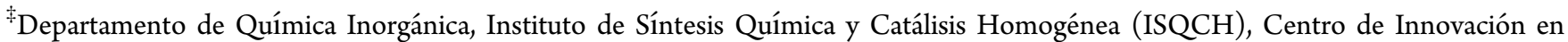
Química Avanzada (ORFEO-CINQA), Universidad de Zaragoza-CSIC, 50009 Zaragoza, Spain

Supporting Information

ABSTRACT: The amide-directed synthesis of five-coordinate osmium alkylidene derivatives from alkynes is reported. These types of complexes, which have been elusive until now because of the tendency of osmium to give hydride alkylidyne species, are prepared by reaction of the dihydride $\mathrm{OsH}_{2} \mathrm{Cl}_{2}\left(\mathrm{P}^{\mathrm{i}} \mathrm{Pr}_{3}\right)_{2}(\mathbf{1})$ with terminal alkynes containing a distal amide group. Complex 1 reacts with $\mathrm{N}$-phenylhex-5-ynamide and $\mathrm{N}$-phenylhepta-6-

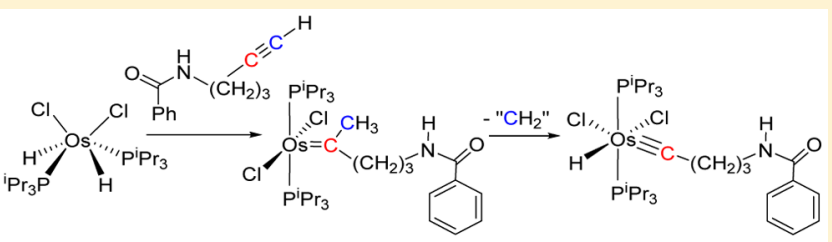
ynamide to give $\mathrm{OsCl}_{2}\left\{=\mathrm{C}\left(\mathrm{CH}_{3}\right)\left(\mathrm{CH}_{2}\right)_{n} \mathrm{NH}(\mathrm{CO}) \mathrm{Ph}\right\}\left(\mathrm{P}^{\mathrm{i}} \mathrm{Pr}_{3}\right)_{2}(n=3(2), 4(3))$. The relative position of carbonyl and $\mathrm{NH}$ groups in the organic substrates has no influence on the reaction. Thus, treatment of 1 with $\mathrm{N}$-(pent-4-yn-1-yl)benzamide leads to $\mathrm{OsCl}_{2}\left\{=\mathrm{C}\left(\mathrm{CH}_{3}\right)\left(\mathrm{CH}_{2}\right)_{3} \mathrm{NHC}(\mathrm{O}) \mathrm{Ph}\right\}\left(\mathrm{P}^{\mathrm{i}} \mathrm{Pr}_{3}\right)_{2}(4)$. The new compounds are intermediate species in the cleavage of the $\mathrm{C}-\mathrm{C}$ triple bond of the alkynes. Under mild conditions, they undergo the rupture of the $\mathrm{C}_{\alpha}-\mathrm{CH}_{3}$ bond of the alkylidene, which comes from the alkyne triple bond, to afford six-coordinate hydride-alkylidyne derivatives. In dichloromethane, complex 2 gives a 10:7 mixture of $\mathrm{OsHCl}_{2}\left\{\equiv \mathrm{C}\left(\mathrm{CH}_{2}\right)_{3} \mathrm{C}(\mathrm{O}) \mathrm{NHPh}\right\}\left(\mathrm{P}^{\mathrm{i}} \mathrm{Pr}_{3}\right)_{2}$ (5) and $\mathrm{OsHCl}_{2}\left\{\equiv \mathrm{CCH}\left(\mathrm{CH}_{3}\right)\left(\mathrm{CH}_{2}\right)_{2} \mathrm{C}(\mathrm{O}) \mathrm{NHPh}\right\}\left(\mathrm{P}^{\mathrm{i}} \mathrm{Pr}_{3}\right)_{2}$ (6). The first complex contains a linear separation between the alkylidyne $\mathrm{C}_{\alpha}$ atom and the amide group, whereas the spacer is branched in the second complex. In contrast to the case for $\mathbf{2}$, complex 4 selectively affords $\mathrm{OsHCl}_{2}\left\{\equiv \mathrm{C}\left(\mathrm{CH}_{2}\right)_{3} \mathrm{NHC}(\mathrm{O}) \mathrm{Ph}\right\}\left(\mathrm{P}^{\mathrm{i}} \mathrm{Pr}_{3}\right)_{2}(7)$. In spite of their instability, these compounds give the alkylidene-allene metathesis, being a useful entry to five-coordinate vinylidene complexes, including the dicarbon-disubstituted $\mathrm{OsCl}_{2}\left(=\mathrm{C}=\mathrm{CMe}_{2}\right)\left(\mathrm{P}^{\mathrm{i}} \mathrm{Pr}_{3}\right)_{2}(\mathbf{8})$ and the monosubstituted $\mathrm{OsCl}_{2}(=\mathrm{C}=\mathrm{CHCy})\left(\mathrm{P}^{\mathrm{i}} \mathrm{Pr}_{3}\right)_{2}(\mathbf{9})$.

\section{INTRODUCTION}

One of the milestones in the chemistry of the last few decades is without doubt the discovery of well-defined ruthenium alkylidene catalysts for olefin metathesis. ${ }^{1}$ Inspired by methodologies previously used to prepare tungsten alkylidenes, in 1992 and 1993, Grubbs and co-workers carried out the addition of diphenylcyclopropene to $\mathrm{RuCl}_{2}\left(\mathrm{PPh}_{3}\right)_{3}$, followed by phosphine exchange, which gave rise to the five-coordinate alkenylalkylidene derivatives $\mathrm{RuCl}_{2}\left(=\mathrm{CHCH}=\mathrm{CPh}_{2}\right)\left(\mathrm{PR}_{3}\right)_{2}$ (Scheme 1). ${ }^{2}$ In 1995, they extended the procedure to alkyl-

Scheme 1

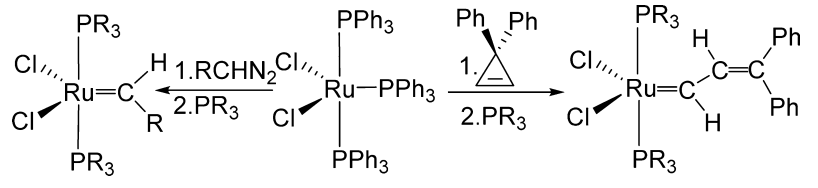

and arylalkylidenes by using alkyl- and aryldiazoalkanes instead of diphenylcyclopropene. ${ }^{3}$

We worked on the osmium counterparts, in parallel. Thus, in 1993, we reported that the reactions of the complex $\mathrm{OsH}_{2} \mathrm{Cl}_{2}\left(\mathrm{P}^{\mathrm{i}} \mathrm{Pr}_{3}\right)_{2}$ with terminal alkynes, alkynols, and enynes yield the hydride alkylidyne oxidized forms (Scheme 2). ${ }^{4}$ In 1998, Caulton and co-workers observed that the reactions with olefins led to equimolecular amounts of hydrogenated olefin and

Scheme 2

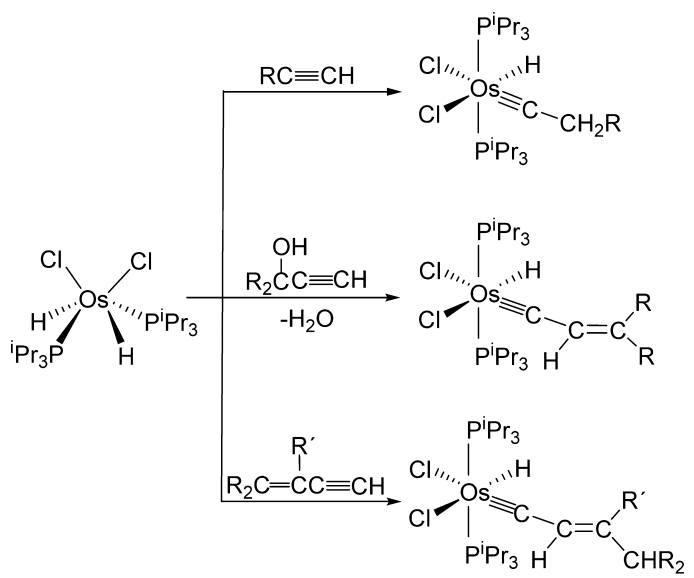

Received: September 11, 2015

Published: December 31, 2015 
the corresponding hydride alkylidyne derivatives. ${ }^{5}$ Most recently, we have shown that these types of compounds can be also prepared from gem-disubstituted allenes and internal enynes. ${ }^{6}$ The behavior of $\mathrm{OsH}_{2} \mathrm{Cl}_{2}\left(\mathrm{P}^{\mathrm{i}} \mathrm{Pr}_{3}\right)_{2}$ is common for unsaturated osmium dihydride complexes, affording dihydrogen tautomers by coordination of electron-poor Lewis bases.?

The ruthenium alkylidene complexes shown in Scheme 1 and the osmium hydride-alkylidyne derivatives of Scheme 2 are both parts of the same redox equilibrium (eq 1). Ruthenium, more oxidizing than osmium, favors the reduced form. However,<smiles>[R]/C=N\C#CC#[W]</smiles>

osmium is more reducing than ruthenium and, preferring saturated species, stabilizes the saturated oxidized form. The transformation from alkylidyne to alkylidene via hydride migration has been reported for a variety of metals of groups $6-8 .{ }^{8}$ The reverse reaction, in which a 1,2-hydrogen shift from the alkylidene $\mathrm{C}_{\alpha}$ atom to the metal occurs, has been mainly observed for osmium ${ }^{9}$ and rhenium. ${ }^{10}$ Because the reactions summarized by eq 1 are redox processes, the position of the equilibria and the activation energy of the transformation are governed not only by the metal center but also by the coligands of the complexes. For instance, the sequential replacement of the chloride ligands of $\mathrm{OsHCl}_{2}\left(\equiv \mathrm{CCH}=\mathrm{CPh}_{2}\right)\left(\mathrm{P}^{\mathrm{i}} \mathrm{Pr}_{3}\right)_{2}$ by acetonitrile molecules produces a sequential decrease of the activation energy of the hydride migration from the metal center to the alkylidyne carbon atom, as a consequence of the gradual decrease of the electron richness of the metal center. ${ }^{11} \mathrm{~A}$ carbonyl group increases further the stability of the alkylidene form. ${ }^{12}$

Five-coordinate osmium alkylidene complexes related to those shown in Scheme 1 are largely unknown, with the notable exception of two cyclopentadienylidene derivatives described by Lin, Jia, and co-workers, resulting from a ligand rearrangement of unstable osmabenzyne species (eq 2). ${ }^{13}$ Grubbs has also reported that the precursor $\mathrm{OsCl}_{2}\left(\mathrm{PPh}_{3}\right)_{3}$ undergoes a reaction

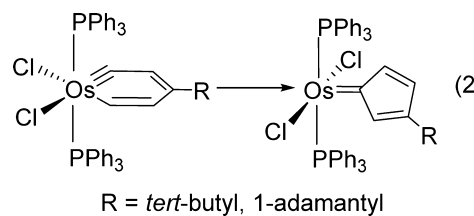

similar to that of $\mathrm{RuCl}_{2}\left(\mathrm{PPh}_{3}\right)_{3}$ with diphenylcyclopropene, to afford the osmium analogues of $\mathrm{RuCl}_{2}\left(=\mathrm{CHCCH}=\mathrm{CPh}_{2}\right)$ $\left(\mathrm{PPh}_{3}\right)_{2}{ }^{2 \mathrm{a}, 14}$ although no experimental evidence has been given.

DFT calculations suggest that five-coordinate osmium alkylidene and six-coordinate osmium hydride alkylidyne have similar energies. ${ }^{11}$ Therefore, at first glance, the alkylidene form might be accessible, provided there is a viable synthetic approach and relatively high activation energy for the interconversion. Herein we demonstrate that introducing an amide group in the alkyllic chain of the substituent of a terminal alkyne allows control of the regioselectivity of its reaction with $\mathrm{OsH}_{2} \mathrm{Cl}_{2}\left(\mathrm{P}^{\mathrm{i}} \mathrm{Pr}_{3}\right)_{2}$ and generates the otherwise elusive five-coordinate alkylidene osmium derivatives instead of standard hydride alkylidyne complexes. We also show that they are intermediate species for the cleavage of the carbon-carbon triple bond of the alkyne and present an entry to interesting vinylidene complexes by metathesis with allenes.

\section{RESULTS AND DISCUSSION}

Five-Coordinate Alkylidene Complexes. In recent years there have been many reports on the use of internal directing groups to control reaction rates and selectivity in metalpromoted processes. ${ }^{15}$ In some cases these groups are located in relatively distant positions of the reaction functionality. ${ }^{16} \mathrm{On}$ these bases we wanted to explore the effect of a weakly coordinating distal amide group in the reaction of terminal alkynes with the dihydride complex $\mathrm{OsH}_{2} \mathrm{Cl}_{2}\left(\mathrm{P}^{\mathrm{i}} \mathrm{Pr}_{3}\right)_{2}$ (1). In contrast to reactions shown in Scheme 2, stirring of this compound with 2.0 equiv of $N$-phenylhex-5-ynamide and $\mathrm{N}$-phenylhept-6-ynamide, in fluorobenzene, at room temperature leads to the alkylidene derivatives $\mathrm{OsCl}_{2}\left\{=\mathrm{C}\left(\mathrm{CH}_{3}\right)\right.$ $\left.\left(\mathrm{CH}_{2}\right)_{n} \mathrm{C}(\mathrm{O}) \mathrm{NHPh}\right\}\left(\mathrm{P}^{\mathrm{i}} \mathrm{Pr}_{3}\right)_{2}(n=3$ (2), $4(3))$. These products result from the coordination of the alkyne moiety to the osmium atom of $\mathbf{1}$ and the subsequent migration of the hydride ligands to the terminal carbon atom (eq 3). The reactions took place in about $70 \%$ yield, and therefore complexes $\mathbf{2}$ and $\mathbf{3}$ were isolated as pure purple solids in a moderate yield of over $40 \%$.

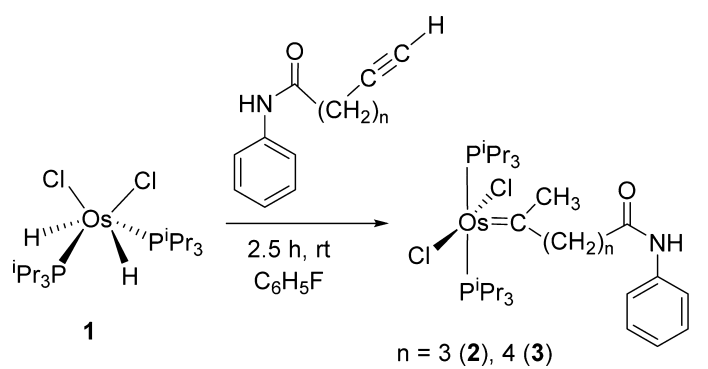

The formation of these unusual compounds was confirmed by means of the X-ray structure of 2 . Figure 1 gives a view of the

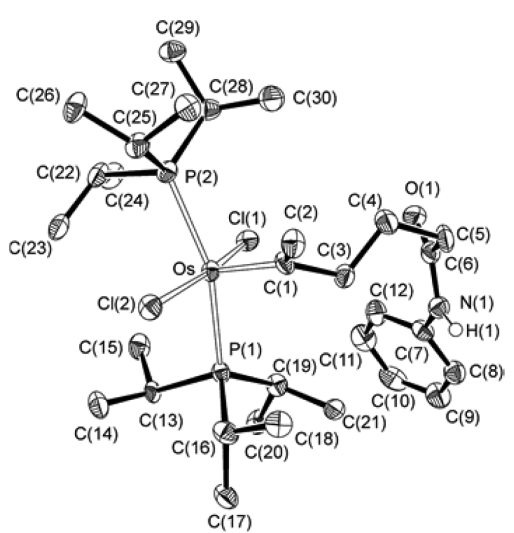

Figure 1. Molecular diagram of complex 2 (50\% probability ellipsoids). Hydrogen atoms (except $\mathrm{N}-\mathrm{H}$ ) are omitted for clarity. Selected bond lengths $(\AA)$ and angles $(\mathrm{deg})$ : Os-C $(1)=1.862(5), \mathrm{Os}-\mathrm{Cl}(1)=$ 2.3901(14), Os- $\mathrm{Cl}(2)=2.4022(14), \mathrm{C}(1)-\mathrm{C}(2)=1.511(8)$, $\mathrm{O}(1)-\mathrm{C}(6)=1.211(8), \mathrm{N}(1)-\mathrm{C}(6)=1.355(8), \mathrm{N}(1)-\mathrm{C}(7)=$ 1.427(8); $\mathrm{P}(1)-\mathrm{Os}-\mathrm{P}(2)=159.42(5), \mathrm{Cl}(1)-\mathrm{Os}-\mathrm{Cl}(2)=168.30(5)$.

molecule. The geometry around the metal center can be rationalized as a square pyramid with the alkylidene in the apex, trans phosphines $\left(\mathrm{P}(1)-\mathrm{Os}-\mathrm{P}(2)=159.42(5)^{\circ}\right)$, and trans chlorides $\left(\mathrm{Cl}(1)-\mathrm{Os}-\mathrm{Cl}(2)=168.30(5)^{\circ}\right)$. The four atoms $\mathrm{P}(1), \mathrm{P}(2), \mathrm{Cl}(1)$, and $\mathrm{Cl}(2)$ forming the base are approximately in one plane, whereas the osmium atom is located $0.3373(8) \AA$ above this plane toward the apical position. The Os-C(1) bond length of $1.862(5) \AA$ supports the Os-C 
double-bond formulation. ${ }^{12,13,17}$ In agreement with the $\mathrm{sp}^{2}$ hybridization at $\mathrm{C}(1)$, the angles around this atom are between 112.1(5) and $124.2(4)^{\circ}$. An extended view of the structure (Figure 2) reveals that the molecules of this complex form

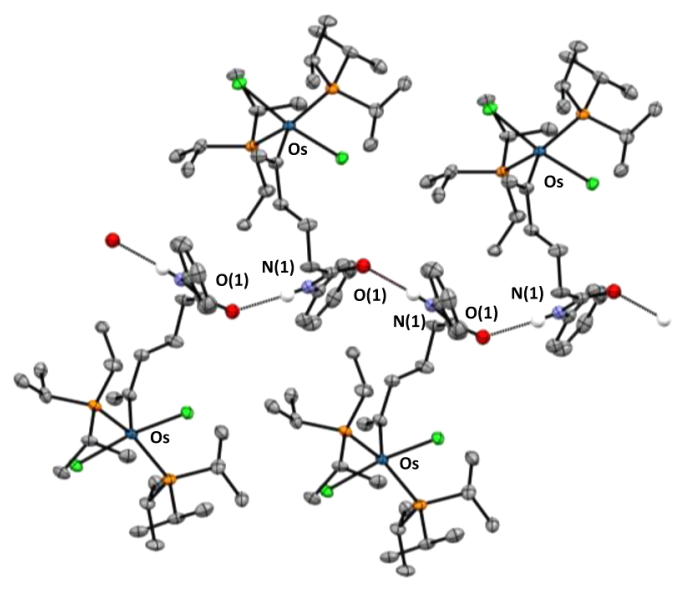

Figure 2. View of the interaction via hydrogen bonding in the structure of 2 (symmetry growing operation $-x+1 / 2,-y, z-1 / 2$, plus translation in $z$ ).

infinite chains by means of intermolecular $\mathrm{N}-\mathrm{H} \cdots \mathrm{O}$ hydrogen bonds between the $\mathrm{NH}$ of the amide of a molecule and the amidic oxygen atom of the adjacent one. Thus, the intermolecular $\mathrm{H}(1)-\mathrm{O}(1)$ separation of 2.05(7) $\AA$ is shorter than the sum of the van der Waals radii of hydrogen and oxygen $\left(r_{\mathrm{vdW}}(\mathrm{H})=1.20 \AA ; r_{\mathrm{vdW}}(\mathrm{O})=1.52 \AA\right),{ }^{18}$ whereas the $\mathrm{N}(1)-\mathrm{H}(1)-\mathrm{O}(1)$ angle is almost linear $\left(167(7)^{\circ}\right)$.

The ${ }^{13} \mathrm{C}\left\{{ }^{1} \mathrm{H}\right\}$ and ${ }^{31} \mathrm{P}\left\{{ }^{1} \mathrm{H}\right\}$ NMR spectra of $\mathbf{2}$ and 3 , in dichloromethane- $d_{2}$, at room temperature are consistent with the structure shown in Figure 1. The ${ }^{13} \mathrm{C}\left\{{ }^{1} \mathrm{H}\right\}$ NMR spectra contain the characteristic low-field resonance corresponding to the metalated alkylidene carbon atom at about $273 \mathrm{ppm}$, whereas in agreement with equivalent phosphines, the ${ }^{31} \mathrm{P}\left\{{ }^{1} \mathrm{H}\right\} \mathrm{NMR}$ spectra show a singlet at $12.1 \mathrm{ppm}$ for 2 and at $10.0 \mathrm{ppm}$ for 3 .

The transformation also occurs in substrates in which the alkyne and the amide are connected through the nitrogen instead of the carbonyl group. Thus, the treatment of fluorobenzene solutions of 1 with 2.0 equiv of $\mathrm{N}$-(pent-4-yn-1-yl)benzamide, at room temperature, leads to $\mathrm{OsCl}_{2}\left\{=\mathrm{C}\left(\mathrm{CH}_{3}\right)\left(\mathrm{CH}_{2}\right)_{3} \mathrm{NHC}(\mathrm{O})\right.$ $\mathrm{Ph}\}\left(\mathrm{P}^{\mathrm{i}} \mathrm{Pr}_{3}\right)_{2}$ (4), which was isolated as a purple solid in $35 \%$ yield, according to eq 4 . In agreement with 2 and 3 , the ${ }^{13} \mathrm{C}\left\{{ }^{1} \mathrm{H}\right\}$ NMR

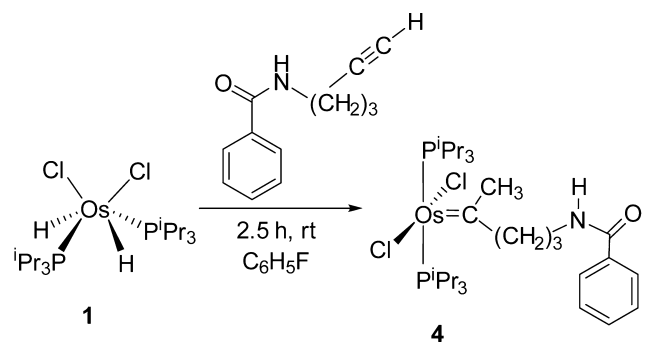

spectrum of this compound, in dichloromethane- $d_{2}$, at room temperature, contains a triplet $\left({ }^{2} J_{\mathrm{C}-\mathrm{P}}=4.3 \mathrm{~Hz}\right)$ at $272.7 \mathrm{ppm}$, corresponding to the $\mathrm{C}_{\alpha}$ atom of the alkylidene, whereas the ${ }^{31} \mathrm{P}\left\{{ }^{1} \mathrm{H}\right\}$ NMR spectrum shows a singlet at $8.7 \mathrm{ppm}$ due to the equivalent phosphines.

The difference in behavior of the substrates shown in Scheme 2 and in eqs 3 and 4 merits some additional comments. It has been proposed that the coordination of the triple bond to the osmium atom of 1 produces the reduction of the metal center to afford $\pi$-alkyne dihydrogen species. These intermediates undergo $\mathrm{HCl}$ elimination and the tautomerization of the $\pi$-alkyne to vinylidene. Thus, the addition of the proton of the acid to the electrophilic $\mathrm{C}_{\beta}$-atom of the vinylidene and the coordination of the anion to the metal center yield the hydride alkylidyne derivatives ${ }^{4}$ (path a in Scheme 3). In agreement with this, it has been observed that, in the presence of a base, the six-coordinate hydride alkylidyne complexes afford five-coordinate hydride vinylidene species. ${ }^{19}$ In the current case, the distal amide group prevents the tautomerization of the triple bond as a consequence of the weak coordination of its oxygen atom, which also exerts a directing effect for the hydride migration (path $\mathbf{b}$ in Scheme 3). Thus, there is an insertion of the triple bond into the $\mathrm{Os}-\mathrm{H}$ bond of the generated monohydrides, followed by the addition of the proton of the eliminated $\mathrm{HCl}$ to the $\mathrm{C}_{\beta}$ atom of the resulting $\alpha$ substituted alkenyl group, along with the displacement of the coordinated carbonyl group by chloride to give the alkylidene derivatives.

Alkylidene to Hydride Alkylidyne Evolution: The Alkylidene as Intermediate in the Cleavage of the Alkyne Triple Bond. Complexes 2 and $\mathbf{4}$ both evolve from alkylidene to hydride alkylidyne in spite of the disubstituted character of the alkylidene $\mathrm{C}_{\alpha}$ atom.

Complex 2 experiences two different transformations, which are competitive in dichloromethane at $60{ }^{\circ} \mathrm{C}$ (Scheme 4). The migration of the methyl group from the $\mathrm{C}_{\alpha}$ atom of the alkylidene ligand to the metal center and a subsequent methylidene extrusion ${ }^{20,21}$ yield the hydride alkylidyne derivative $\mathrm{OsHCl}_{2}$ $\left\{\equiv \mathrm{C}\left(\mathrm{CH}_{2}\right)_{3} \mathrm{CONHPh}\right\}\left(\mathrm{P}^{\mathrm{i}} \mathrm{Pr}_{3}\right)_{2}$ (5), containing a linear spacer between the alkylidyne $\mathrm{C}_{\alpha}$ atom and the amide (pathway $\mathrm{a}$ in Scheme 4). On the other hand, the activation of one of the $\mathrm{C}-\mathrm{H}$ bonds of the $\mathrm{C}_{\beta} \mathrm{H}_{2}$ group and a concerted 1,2-methyl shift in the resulting osmacyclopropene ${ }^{22}$ give $\mathrm{OsHCl}\left\{\equiv \mathrm{CCH}\left(\mathrm{CH}_{3}\right)\right.$ $\left.\left(\mathrm{CH}_{2}\right)_{2} \mathrm{C}(\mathrm{O}) \mathrm{NHPh}\right\}\left(\mathrm{P}^{\mathrm{i}} \mathrm{Pr}_{3}\right)_{2}$ (6), with a branched spacer between the alkylidyne $\mathrm{C}_{\alpha}$ atom and the amide (pathway $\mathbf{b}$ in Scheme 4). As a consequence of both processes, a 10:7 mixture of 5 and 6 was formed after $48 \mathrm{~h}$.

White crystals of $\mathbf{5}$ suitable for X-ray diffraction analysis were obtained from the mixture. Figure 3 gives a view of the structure. The coordination around the osmium atom can be rationalized as a distorted octahedron with the phosphines occupying trans positions $(\mathrm{P}(1)-\mathrm{Os}-\mathrm{P}(2)=166.17(4) \AA)$. The perpendicular plane is formed by the cis-disposed chloride ligands, the alkylidyne trans to $\mathrm{Cl}(1)\left(\mathrm{C}(1)-\mathrm{Os}-\mathrm{Cl}(1)=177.14(16)^{\circ}\right)$, and the hydride disposed trans to $\mathrm{Cl}(2)(\mathrm{H}(01)-\mathrm{Os}-\mathrm{Cl}(2)=$ $\left.167.9(15)^{\circ}\right)$. The Os-C(1) bond length of $1.706(5) \AA$ is fully consistent with an Os-C(1) triple bond formulation. ${ }^{4,6,7,23}$ The ${ }^{1} \mathrm{H},{ }^{13} \mathrm{C}\left\{{ }^{1} \mathrm{H}\right\}$, and ${ }^{31} \mathrm{P}\left\{{ }^{1} \mathrm{H}\right\}$ NMR spectra, in dichloromethane- $d_{2}$, at room temperature are consistent with the structure shown in Figure 3. In accordance with the presence of the hydride ligand, the ${ }^{1} \mathrm{H}$ NMR spectrum contains at $-7.57 \mathrm{ppm}$ a triplet with a $\mathrm{H}-\mathrm{P}$ coupling constant of $16.2 \mathrm{~Hz}$. In the ${ }^{13} \mathrm{C}\left\{{ }^{1} \mathrm{H}\right\} \mathrm{NMR}$ spectrum the alkylidyne $\mathrm{C}(1)$ atom displays a triplet $\left({ }^{2} J_{\mathrm{C}-\mathrm{P}}=\right.$ $11.4 \mathrm{~Hz}$ ) at $267.1 \mathrm{ppm}$. As expected for equivalent phosphines, the ${ }^{31} \mathrm{P}\left\{{ }^{1} \mathrm{H}\right\}$ NMR spectrum shows a singlet at $23.7 \mathrm{ppm}$. An extended view of the structure (Figure 4) reveals that, like those of $\mathbf{2}$, the molecules of this complex form infinite chains, in this case by means of intermolecular $\mathrm{N}-\mathrm{H} \cdots \mathrm{Cl}(2)$ hydrogen bonds (chlorine trans to hydride). Thus, the intermolecular $\mathrm{H}(1) \cdots$ $\mathrm{Cl}(2)$ separation of $2.32(5) \AA$ is shorter than the sum of the 


\section{Scheme 3}

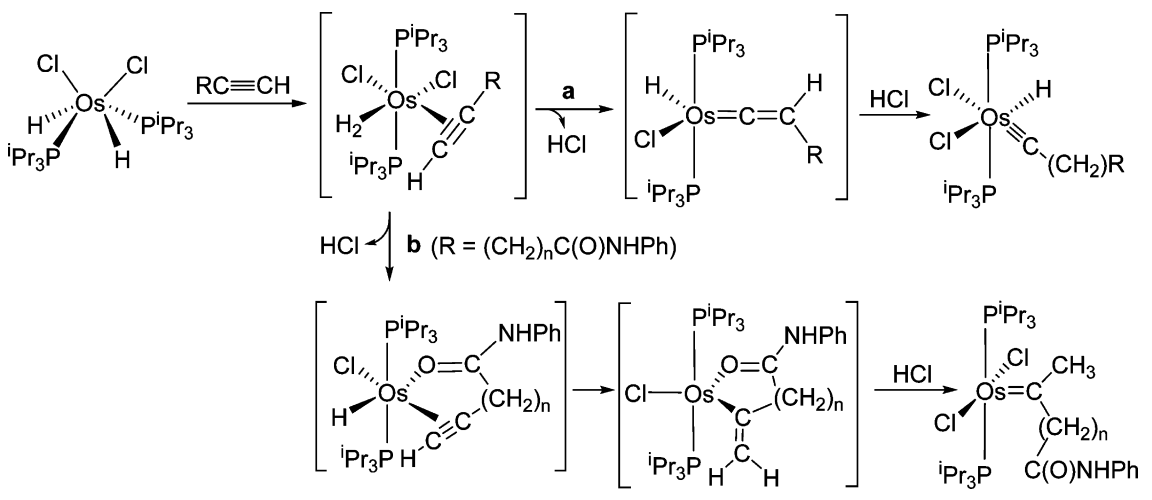

Scheme 4
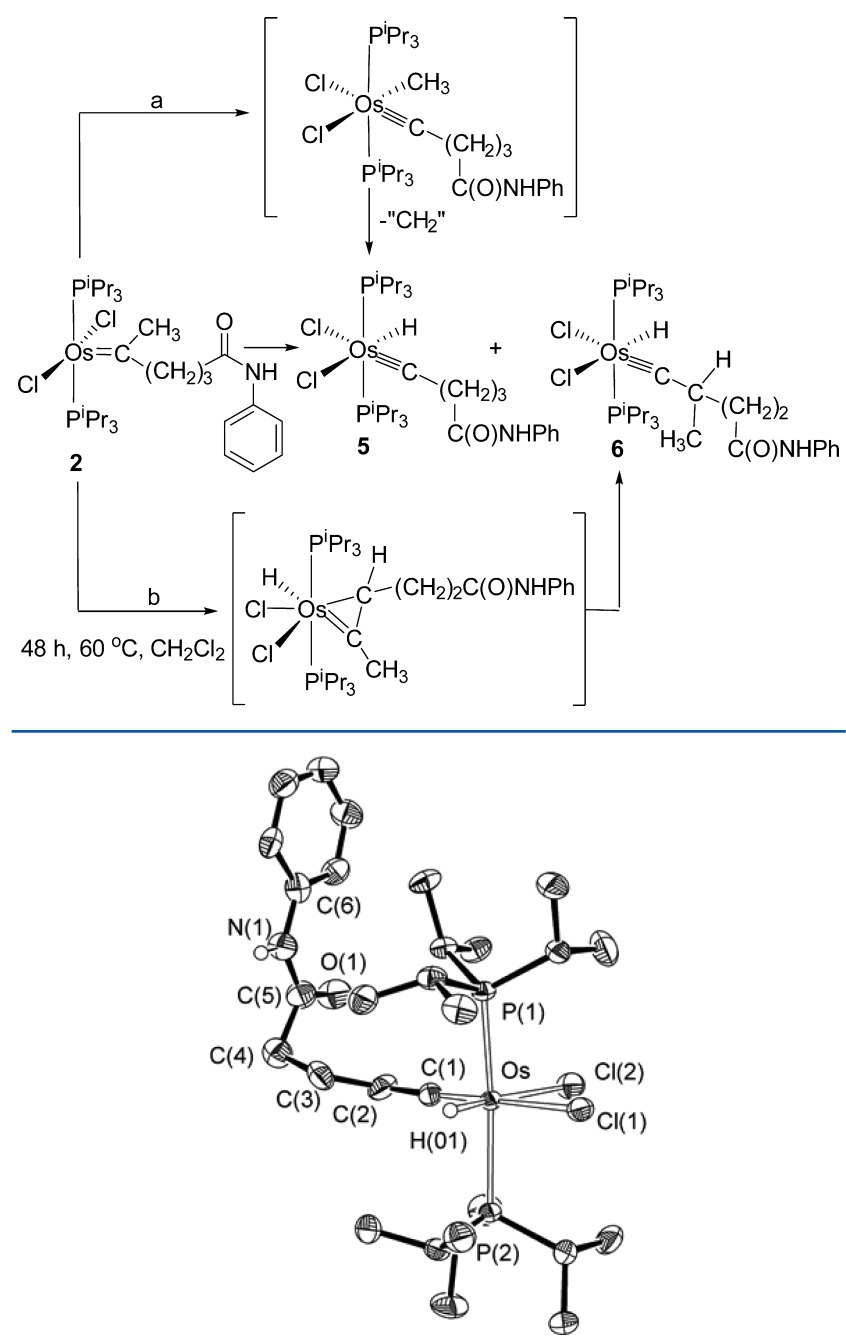

Figure 3. Molecular diagram of complex $\mathbf{5}$ ( $50 \%$ probability ellipsoids). Hydrogen atoms (except hydride and $\mathrm{NH}$ ) are omitted for clarity. Selected bond lengths $(\AA)$ and angles (deg): Os-C $(1)=1.706(5)$, Os$\mathrm{Cl}(1)=2.4858(14), \mathrm{Os}-\mathrm{Cl}(2)=2.5268(13) ; \mathrm{P}(1)-\mathrm{Os}-\mathrm{P}(2)=$ 166.17(4), $\mathrm{C}(1)-\mathrm{Os}-\mathrm{Cl}(1)=177.14(16), \mathrm{H}(01)-\mathrm{Os}-\mathrm{Cl}(2)=$ $167.9(15)$.

van der Waals radii of hydrogen and chlorine $\left(r_{\mathrm{vdW}}(\mathrm{Cl})=1.75 \AA\right)^{18}$ and the $\mathrm{N}(1)-\mathrm{H}(1)-\mathrm{Cl}(2)$ angle is almost linear $\left(169(4)^{\circ}\right)$.

Complex 6 was characterized by NMR spectroscopy, in dichloromethane- $d_{2}$ at room temperature, including bidimen-

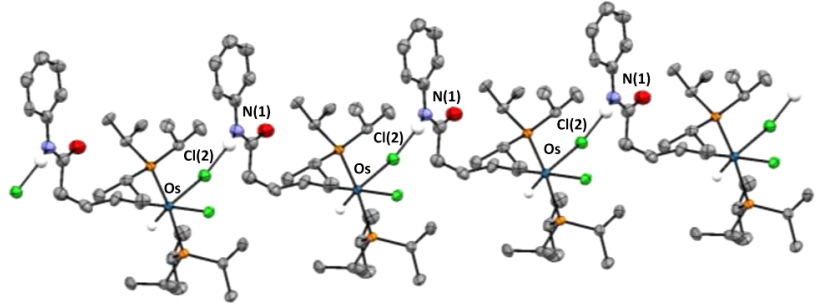

Figure 4. View of the interaction via hydrogen bonding in the structure of 5 (symmetry growing operation $x-1, y, z$, plus translation in $x$ ).

sional ${ }^{1} \mathrm{H}-{ }^{13} \mathrm{C}$ HSQC and ${ }^{1} \mathrm{H}-{ }^{13} \mathrm{C}$ HMBC spectra (see the Supporting Information). In agreement with the presence of the hydride ligand, the ${ }^{1} \mathrm{H}$ NMR spectrum shows the characteristic high-field resonance at $-7.07 \mathrm{ppm}$, which appears as a triplet with a $\mathrm{H}-\mathrm{P}$ coupling constant of $16.2 \mathrm{~Hz}$. The most noticeable signal in the low-field region is a singlet at $1.74 \mathrm{ppm}$, corresponding to the methyl group of the branching separator. In the ${ }^{13} \mathrm{C}\left\{{ }^{1} \mathrm{H}\right\}$ NMR spectrum, the alkylidyne $\mathrm{C}_{\alpha}$ resonance is observed at $271.8 \mathrm{ppm}$, as a triplet with a $\mathrm{C}-\mathrm{P}$ coupling constant of $11.4 \mathrm{~Hz}$, whereas the signal due to the methyl group of the branched spacer appears at $22.5 \mathrm{ppm}$ as a singlet. A singlet at $23.9 \mathrm{ppm}$ in the ${ }^{31} \mathrm{P}\left\{{ }^{1} \mathrm{H}\right\}$ NMR spectrum supports the presence of equivalent phosphines in the complex.

The relative position of the carbonyl and the $\mathrm{NH}$ groups in the amide influences the behavior of the alkylidene and the structural properties of the resulting hydride alkylidyne product. In contrast to 2 , complex 4 selectively evolves into $\mathrm{OsHCl}_{2}\{\equiv \mathrm{C}$ $\left.\left(\mathrm{CH}_{2}\right)_{3} \mathrm{NHC}(\mathrm{O}) \mathrm{Ph}\right\}\left(\mathrm{P}^{\mathrm{i}} \mathrm{Pr}_{3}\right)_{2}(7)$, the benzamide counterpart of 5, containing a linear spacer (eq 5). The transformation is quantitative after $7 \mathrm{~h}$, although complex 7 was isolated as a white

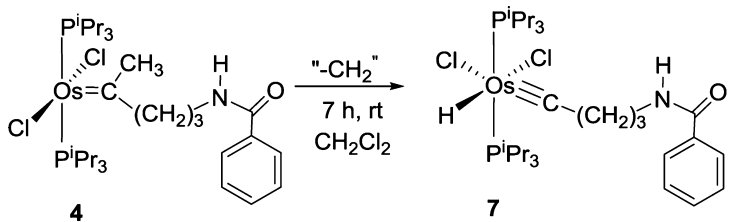

solid in low yield (35\%) due to its high solubility in the usual organic solvents.

Complex 7 was also characterized by X-ray diffraction analysis. Figure 5 shows a view of the molecule. The coordination polyhedron around the osmium atom resembles that of 5 with $\mathrm{P}(1)-\mathrm{Os}-\mathrm{P}(2), \mathrm{C}(1)-\mathrm{Os}-\mathrm{Cl}(2)$, and $\mathrm{H}(01)-\mathrm{Os}-\mathrm{Cl}(1)$ angles of $167.15(3), 172.28(11)$, and $167.6(12)^{\circ}$, respectively. The Os-C(1) bond length of $1.715(4) \AA$ is statistically identical 


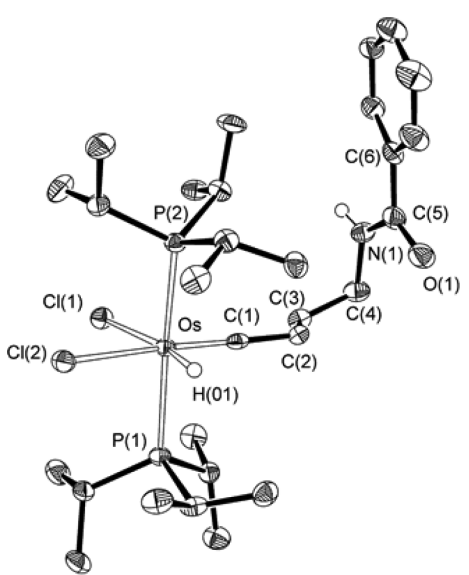

Figure 5. Molecular diagram of complex 7 (50\% probability ellipsoids). Hydrogen atoms (except hydride and $\mathrm{NH}$ ) are omitted for clarity. Selected bond lengths $(\AA \AA)$ and angles $(\mathrm{deg})$ : Os-C $(1)=1.715(4)$, Os$\mathrm{Cl}(1)=2.5169(10), \mathrm{Os}-\mathrm{Cl}(2)=2.4845(10) ; \mathrm{P}(1)-\mathrm{Os}-\mathrm{P}(2)=167.15(3)$, $\mathrm{C}(1)-\mathrm{Os}-\mathrm{Cl}(1)=101.74(12), \mathrm{H}(01)-\mathrm{Os}-\mathrm{Cl}(1)=167.6(12), \mathrm{C}(1)-$ $\mathrm{Os}-\mathrm{Cl}(2)=172.28(11)$.

with the osmium alkylidyne separation in 5 . The ${ }^{1} \mathrm{H},{ }^{13} \mathrm{C}\left\{{ }^{1} \mathrm{H}\right\}$, and ${ }^{31} \mathrm{P}\left\{{ }^{1} \mathrm{H}\right\}$ NMR spectra, in dichloromethane- $d_{2}$, at room temperature are consistent with the structure shown in Figure 5 and agree well with those of 5 . Thus, a triplet $\left({ }^{2} J_{\mathrm{H}-\mathrm{P}}=16.8 \mathrm{~Hz}\right)$ at $-7.17 \mathrm{ppm}$ in the ${ }^{1} \mathrm{H}$ NMR spectrum, a triplet $\left({ }^{2} J_{\mathrm{C}-\mathrm{P}}=10.8 \mathrm{~Hz}\right)$ at $270.5 \mathrm{ppm}$ in the ${ }^{13} \mathrm{C}\left\{{ }^{1} \mathrm{H}\right\} \mathrm{NMR}$ spectrum, and a singlet at $21.4 \mathrm{ppm}$ in the ${ }^{31} \mathrm{P}\left\{{ }^{1} \mathrm{H}\right\}$ NMR spectrum are the characteristic spectroscopic features of this compound. An extended view of the structure reveals that the separation between the $\mathrm{NH}$ hydrogen atom and the chloride ligand trans disposed to hydride is also, in this case, short $(\mathrm{H}(1) \cdots \mathrm{Cl}(1)=2.51(4) \AA)$. However, in contrast to the case for $\mathbf{5}$, the association gives rise to dimers (Figure 6) instead of infinite chains.

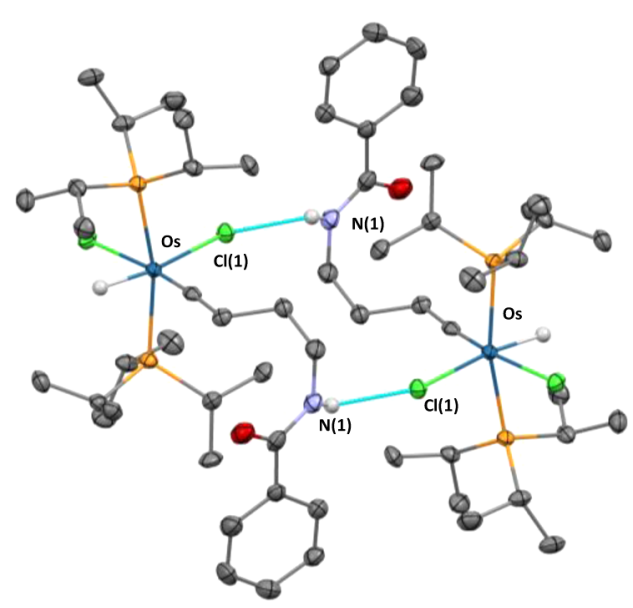

Figure 6. View of the interaction via hydrogen bonding in the structure of 7 (symmetry code $-x+1,-y+1, z$ ).

The selective carbon-carbon bond cleavage by transitionmetal complexes is of great interest due to its fundamental scientific relevance and potential utility in organic synthesis. ${ }^{24}$ The carbon-carbon triple bond is known to be one of the strongest bonds in organic molecules. In this contest, the reactions summarized in Scheme 4 and eq 5 are certainly notable because they prove that the five-coordinate osmium alkenylidene complexes $\mathbf{2}$ and $\mathbf{4}$ are intermediate species in the osmium-mediated rupture of the carbon-carbon triple bond of $N$-phenylhexen-5ynamide and $N$-(phenyl-4-yn-1-yl)benzamide, respectively, under mild conditions. Previously achieved homogeneous metal-mediated cleavages of the alkyne triple bond have been performed under drastic conditions by means of metathesis reactions, which imply $\mathrm{M}-\mathrm{M}, \mathrm{C}-\mathrm{C}$, and $\mathrm{M}-\mathrm{C}$ triple bonds. ${ }^{25} \mathrm{~A}$ number of metal-mediated cleavages that involved water ${ }^{26}$ and propargyl rearrangement ${ }^{27}$ have been also reported, in addition to strategies involving the transformation of the alkyne into other functionalities. $^{24 c}$

Metathesis of Allenes. It is remarkable that despite the enormous progress in metathesis chemistry along the last decades we are only aware of one example of a metathesis of metal alkylidenes with allenes, consisting of the reaction of $\mathrm{RuCl}_{2}(\mathrm{CHPh})\left(\mathrm{PCy}_{3}\right)_{2}$ with a large excess of propan-1,2-diene. ${ }^{3 \mathrm{~b}}$ Complex 2 reacts with allenes such as 3-methyl-1,2-butadiene and cyclohexylallene to afford five-coordinate vinylidene derivatives (Scheme 5).

\section{Scheme 5}

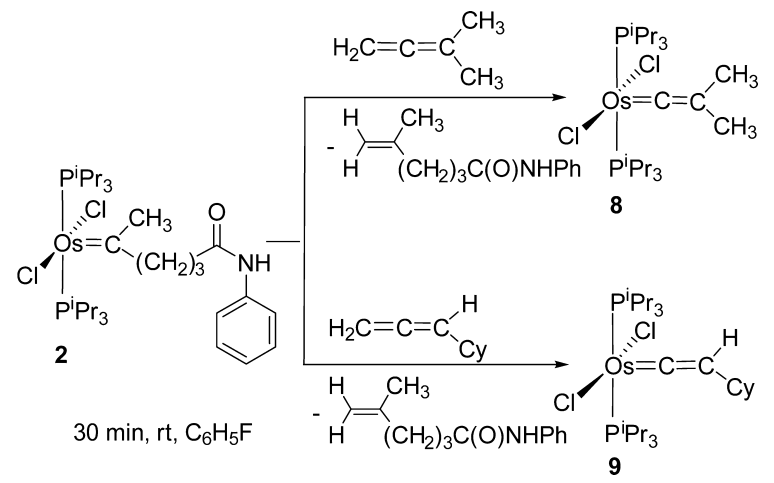

Treatment of fluorobenzene solutions of 2 with 1.5 equiv of 3methyl-1,2-butadiene, at room temperature, leads to 5-methyl- $\mathrm{N}$ phenylhex-5-enamide (isolated and characterized; see the Experimental Section) and $\mathrm{OsCl}_{2}\left(=\mathrm{C}=\mathrm{CMe}_{2}\right)\left(\mathrm{P}^{\mathrm{i}} \mathrm{Pr}_{3}\right)_{2}$ (8), which is notable because it is a rare example of dicarbondisubstituted vinylidene in osmium chemistry. Transition-metal vinylidene complexes are most often synthesized by tautomerization of alkynes, and therefore the majority of them are monosubstituted. ${ }^{8 g, 28}$ Heteroatom-substituted internal alkynes can yield disubstituted vinylidenes with a heteroatom at $\mathrm{C}_{\beta} \cdot{ }^{29} \mathrm{We}$ have described the preparation of osmium borylvinylidene derivatives through a 1,3-boryl shift in alkynyl boryl intermediates. ${ }^{30}$ Dicarbon-disubstituted vinylidenes are generally salts, which have been prepared by electrophilic addition to the $\mathrm{C}_{\beta}$ atom of an alkynyl ligand. ${ }^{31}$ Under appropriate conditions, it is also possible to form dicarbon-disubstituted vinylidenes starting from unfunctionalized internal alkynes. ${ }^{32}$ Vinylidenes with $\mathrm{C}_{\beta}$ incorporated into five- or six-membered rings have been formed by dehydrative cyclization of terminal alkynals ${ }^{33}$ or by means of Diels-Alder reactions between the $\mathrm{C}_{\beta}-\mathrm{C}_{\gamma}$ double bond of an allenylidene ligand and a cyclic diolefin. $^{34}$

Complex 8 was isolated as green crystals, in 57\% yield, and characterized by X-ray diffraction analysis. The structure (Figure 7) proves the metathesis reactions between the alkylidene of $\mathbf{2}$ and the allene. The geometry around the osmium atom can be described as a distorted square pyramid with the vinylidene in the apex, trans phosphines $\left(\mathrm{P}(1)-\mathrm{Os}-\mathrm{P}(1 \mathrm{~A})=173.08(3)^{\circ}\right)$, and trans chlorides $\left(\mathrm{Cl}(1)-\mathrm{Os}-\mathrm{Cl}(1 \mathrm{~A})=153.22(4)^{\circ}\right)$. The donor 


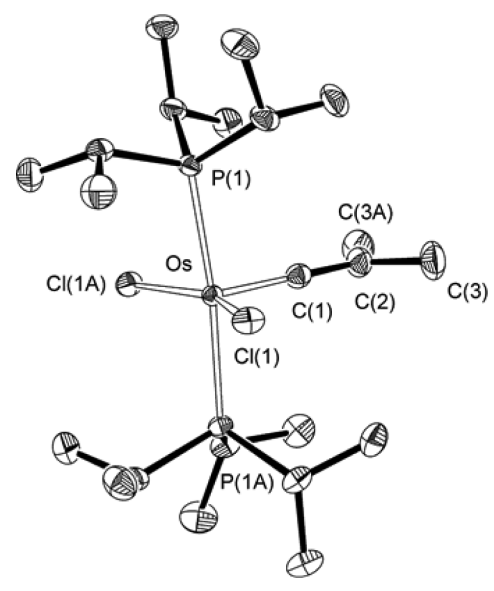

Figure 7. Molecular diagram of complex 8 ( $50 \%$ probability ellipsoids). Hydrogen atoms are omitted for clarity. Selected bond lengths $(\AA)$ and angles (deg): Os- $\mathrm{C}(1)=1.798(4), \mathrm{Os}-\mathrm{Cl}(1)=2.3489(6), \mathrm{C}(1)-$ $\mathrm{C}(2)=1.314(6) ; \mathrm{P}(1)-\mathrm{Os}-\mathrm{P}(1 \mathrm{~A})=173.08(3), \mathrm{Cl}(1)-\mathrm{Os}-\mathrm{Cl}(1 \mathrm{~A})=$ 153.22(4), $\mathrm{C}(1)-\mathrm{Os}-\mathrm{Cl}(1)=103.392(18)$.

atoms forming the base are approximately in one plane, whereas the osmium atom is shifted 0.3447 (5) $\AA$ above this plane toward the apical position. In agreement with other osmium vinylidene compounds, ${ }^{25,30,35}$ the vinylidene is bound to the metal in a linear fashion with an $\mathrm{Os}-\mathrm{C}(1)-\mathrm{C}(2)$ angle of $180^{\circ}$ (crystallographically imposed) and $\mathrm{Os}-\mathrm{C}(1)$ and $\mathrm{C}(1)-\mathrm{C}(2)$ bond lengths of $1.798(4)$ and $1.314(6) \AA$, respectively. In the ${ }^{13} \mathrm{C}\left\{{ }^{1} \mathrm{H}\right\}$ NMR spectrum in benzene- $d_{6}$, at room temperature, the carbon atoms of the unsaturated chain display a triplet $\left({ }^{2} J_{\mathrm{C}-\mathrm{P}}=12.1 \mathrm{~Hz}\right)$ at $271.1\left(\mathrm{C}_{\alpha}\right) \mathrm{ppm}$ and a singlet at $111.0\left(\mathrm{C}_{\beta}\right) \mathrm{ppm}$. As expected for equivalent phosphines, the ${ }^{31} \mathrm{P}\left\{{ }^{1} \mathrm{H}\right\}$ NMR spectrum shows a singlet at $-0.4 \mathrm{ppm}$.

The metathesis of the alkylidene of $\mathbf{2}$ with cyclohexylallene leads to the monosubstituted vinylidene $\mathrm{OsCl}_{2}(=\mathrm{C}=\mathrm{CHCy})$ $\left(\mathrm{P}^{\mathrm{i}} \mathrm{Pr}_{3}\right)_{2}(9)$, which was isolated as a green solid in $47 \%$ yield. Its formation is strongly supported by the ${ }^{13} \mathrm{C}\left\{{ }^{1} \mathrm{H}\right\}$ NMR spectrum of the obtained solid in benzene- $d_{6}$, at room temperature, which shows the characteristic resonances of the unsaturated chain, at $271.9\left(\mathrm{C}_{\alpha}\right)$ and $111.2\left(\mathrm{C}_{\beta}\right)$ ppm, as triplets with $\mathrm{C}-\mathrm{P}$ coupling constants of 10.2 and $4.4 \mathrm{~Hz}$, respectively. In the ${ }^{31} \mathrm{P}\left\{{ }^{1} \mathrm{H}\right\} \mathrm{NMR}$ spectrum, the equivalent phosphines display a singlet at $2.5 \mathrm{ppm}$.

\section{CONCLUDING REMARKS}

This paper reveals the first direct access to five-coordinate osmium alkylidene derivatives. In contrast to ruthenium, these compounds were largely unknown until now, due mainly to the higher reducing power of osmium, which favors the formation of the hydride alkylidyne isomers. We now demonstrate that this important limitation can be solved by introducing a distal amide group at an appropriate position of the alkyllic chain of a terminal alkyne.

The amide function changes the reactivity of terminal alkynes toward the dihydride osmium(IV) complex $\mathrm{OsH}_{2} \mathrm{Cl}_{2}\left(\mathrm{P}^{\mathrm{i}} \mathrm{Pr}_{3}\right)_{2}$. In contrast to the previously used groups, which favor the alkyne to vinylidene tautomerization to finally yield hydride alkylidyne derivatives, the alkylamide substituents prevent the tautomerization of the triple bond, promoting a Markovnikov-type insertion into one of the osmium-hydride bonds of the precursor. Thus, the subsequent 1,3-migration of the other hydride to the $\mathrm{C}_{\beta}\left(\mathrm{sp}^{2}\right)$ atom of the resulting alkenyl intermediate leads to the alkylidene derivatives.
These alkylidene compounds are intermediate species in the metal-mediated rupture of the carbon-carbon triple bond of the initial alkyne. Thus, they are unstable in spite of being disubstituted, something in agreement with the strongly reducing character of osmium and its marked preference to form saturated species. Indeed, the new compounds evolve upon slight heating or long standing toward six-coordinated hydride alkylidyne species, by means of interesting rearrangement processes, including the $\mathrm{C}_{\alpha}-\mathrm{CH}_{3}$ bond of the alkylidene which comes from the alkyne triple bond. These rearrangements consist of either a 1,2-methyl shift from the alkylidene $C_{\alpha}$ atom to the metal center and subsequent methylidene extrusion or a metalpromoted $\mathrm{C}-\mathrm{H}$ bond activation of the $\mathrm{C}_{\beta} \mathrm{H}_{2}$ group of the alkyllic chain along with a 1,2-methyl shift. The alkylidene ligands of these compounds undergo metathesis with allenes to afford five-coordinated vinylidene species, being in this way a useful entry to interesting dicarbon-disubstituted vinylidene complexes.

In conclusion, the presence of a distal amide at the alkyllic chain of the substituent of a terminal alkyne allows the preparation of five-coordinate osmium alkylidene complexes by means of the direct reaction of these substrates with unsaturated dihydride compounds, which afford dihydrogen tautomers by coordination of weak Lewis bases. The new complexes are intermediate species in the osmium-mediated rupture of the carbon-carbon triple bond of these alkynes and useful starting materials for the preparation of dicarbon-disubstituted vinylidenes.

\section{EXPERIMENTAL SECTION}

All reactions were carried out with rigorous exclusion of air using Schlenk-tube techniques. Solvents were obtained oxygen- and water-free from an MBraun solvent purification apparatus. ${ }^{1} \mathrm{H},{ }^{13} \mathrm{C}\left\{{ }^{1} \mathrm{H}\right\}$, and ${ }^{31} \mathrm{P}\left\{{ }^{1} \mathrm{H}\right\}$ NMR spectra were recorded on Bruker 300 ARX, Bruker Avance $300 \mathrm{MHz}$, and Bruker Avance $400 \mathrm{MHz}$ instruments. Chemical shifts (expressed in parts per million) are referenced to residual solvent peaks $\left({ }^{1} \mathrm{H},{ }^{13} \mathrm{C}\left\{{ }^{1} \mathrm{H}\right\}\right)$, or external $85 \% \mathrm{H}_{3} \mathrm{PO}_{4}\left({ }^{31} \mathrm{P}\left\{{ }^{1} \mathrm{H}\right\}\right)$. Coupling constants $J$ and $N$ are given in hertz. Attenuated total reflection infrared spectra (ATR-IR) of solid samples were run on a PerkinElmer Spectrum 100 FT-IR spectrometer. $\mathrm{C}, \mathrm{H}$, and $\mathrm{N}$ analyses were carried out in a PerkinElmer $2400 \mathrm{CHNS} / \mathrm{O}$ analyzer. $\mathrm{OsH}_{2} \mathrm{Cl}_{2}\left(\mathrm{P}^{\mathrm{i}} \mathrm{Pr}_{3}\right)_{2},{ }^{36 \mathrm{a}} \mathrm{N}$-phenylhex-5-ynamide, ${ }^{36 \mathrm{~b}} \mathrm{~N}$-phenylhept-6-ynamide, ${ }^{36 \mathrm{a}}$ and $\mathrm{N}$-(pent-4-yn-1yl)benzamide ${ }^{36 c}$ were prepared following reported methods.

Preparation of Complex 2. A brown solution of $\mathrm{OsH}_{2} \mathrm{Cl}_{2}\left(\mathrm{P}^{\mathrm{i}} \mathrm{Pr}_{3}\right)_{2}$ $(100 \mathrm{mg}, 0.171 \mathrm{mmol})$ in fluorobenzene $(6 \mathrm{~mL})$ was treated with $\mathrm{N}$-phenylhex-5-ynamide $(60 \mathrm{mg}, 0.342 \mathrm{mmol})$ at room temperature. The mixture was stirred for $2.5 \mathrm{~h}$. After this time, the resulting solution was evaporated to dryness. The residue was dissolved in ether and filtered through Celite, and the solvent was removed in vacuo. The subsequent addition of methanol to the residue afforded a purple solid that was washed with methanol $(3 \times 2 \mathrm{~mL})$ and dried in vacuo. Yield: $50 \mathrm{mg}(38 \%)$. Anal. Calcd. for $\mathrm{C}_{30} \mathrm{Cl}_{2} \mathrm{H}_{57} \mathrm{NOOsP}_{2}$ : C, 46.76; H, 7.45; N, 1.81. Found: C, 46.64; H, 7.36; N, 1.74. IR $\left(\mathrm{cm}^{-1}\right): \nu(\mathrm{C}=\mathrm{O}) 1657(\mathrm{~s})$, $\nu(\mathrm{NH}) 3250$ (s). ${ }^{1} \mathrm{H}$ NMR $\left(300 \mathrm{MHz}, \mathrm{CD}_{2} \mathrm{Cl}_{2}, 298 \mathrm{~K}\right): \delta 8.09(\mathrm{br}, 1 \mathrm{H}$, $\mathrm{NH}), 7.59\left(\mathrm{~d},{ }^{3} \mathrm{H}_{\mathrm{H}-\mathrm{H}}=7.8,2 \mathrm{H}, \mathrm{CH} \mathrm{Ph}\right), 7.31\left(\mathrm{dd},{ }^{3} \mathrm{~J}_{\mathrm{H}-\mathrm{H}}=7.8,{ }^{3} J_{\mathrm{H}-\mathrm{H}}=\right.$ 7.8, $2 \mathrm{H}, \mathrm{CH} \mathrm{Ph}), 7.08\left(\mathrm{t},{ }^{3} \mathrm{~J}_{\mathrm{H}-\mathrm{H}}=7.8,1 \mathrm{H}, \mathrm{CH} \mathrm{Ph}\right), 2.90(\mathrm{~m}, 6 \mathrm{H}$, $\left.\mathrm{PCH}\left(\mathrm{CH}_{3}\right)_{2}\right), 2.39\left(\mathrm{~m}, 4 \mathrm{H}, \mathrm{CH}_{2}\right), 1.59\left(\mathrm{~s}, 3 \mathrm{H}, \mathrm{CH}_{3}\right), 1.30$ (overlapped, $\left.2 \mathrm{H}, \mathrm{CH}_{2}\right), 1.30\left(\mathrm{dvt},{ }^{3} \mathrm{~J}_{\mathrm{H}-\mathrm{H}}=6.7, \mathrm{~N}=13.2,36 \mathrm{H}, \mathrm{PCH}\left(\mathrm{CH}_{3}\right)_{2}\right) .{ }^{31} \mathrm{P}\left\{{ }^{1} \mathrm{H}\right\}$ NMR (121.4 MHz, $\left.\mathrm{CD}_{2} \mathrm{Cl}_{2}, 298 \mathrm{~K}\right): \delta 12.1$ (s). ${ }^{13} \mathrm{C}\left\{{ }^{1} \mathrm{H}\right\}$-APT NMR, $\mathrm{HMBC}$, and $\mathrm{HSQC}\left(75.5 \mathrm{MHz}, \mathrm{CD}_{2} \mathrm{Cl}_{2}, 298 \mathrm{~K}\right): \delta 272.8(\mathrm{~s}, \mathrm{Os}=\mathrm{C})$, 171.3 (s, C=O), 138.8 (s, C Ph), 129.1 (s, CH Ph), $124.2(\mathrm{~s}, \mathrm{CH} \mathrm{Ph})$, $120.2(\mathrm{~s}, \mathrm{CH} \mathrm{Ph}), 77.5\left(\mathrm{~s}, \mathrm{CH}_{2}\right), 62.6\left(\mathrm{~s}, \mathrm{CH}_{3}\right), 38.3\left(\mathrm{~s}, \mathrm{CH}_{2}\right), 30.0(\mathrm{~s}$, $\mathrm{CH}_{2}$ ), 23.8 (vt, $\left.\mathrm{N}=21.9, \mathrm{PCH}\left(\mathrm{CH}_{3}\right)_{2}\right), 20.0\left(\mathrm{~s}, \mathrm{PCH}\left(\mathrm{CH}_{3}\right)_{2}\right)$.

Preparation of Complex 3. A brown solution of $\mathrm{OsH}_{2} \mathrm{Cl}_{2}\left(\mathrm{P}^{\mathrm{i}} \mathrm{Pr}_{3}\right)_{2}$ $(100 \mathrm{mg}, 0.171 \mathrm{mmol})$ in fluorobenzene $(6 \mathrm{~mL})$ was treated with $\mathrm{N}$-phenylhept-6-ynamide $(70 \mathrm{mg}, 0.342 \mathrm{mmol})$ at room temperature. 
The mixture was stirred for $2.5 \mathrm{~h}$. After this time, the resulting solution was evaporated to dryness. The residue was dissolved in ether and filtered through Celite, and the solvent was removed in vacuo. The subsequent addition of methanol to the residue afforded a purple solid that was washed with methanol $(3 \times 2 \mathrm{~mL})$ and dried in vacuo. Yield: $53 \mathrm{mg}$ (39\%). Anal. Calcd. for $\mathrm{C}_{31} \mathrm{H}_{59} \mathrm{Cl}_{2} \mathrm{NOOsP}_{2}$ : C, 47.44; $\mathrm{H}, 7.57 ; \mathrm{N}$, 1.78. Found: $\mathrm{C}, 47.25 ; \mathrm{H}, 7.82 ; \mathrm{N}, 1.92$. IR $\left(\mathrm{cm}^{-1}\right): \nu(\mathrm{C}=\mathrm{O}) 1693(\mathrm{~s})$, $\nu(\mathrm{NH}) 3330$ (s). ${ }^{1} \mathrm{H}$ NMR $\left(300 \mathrm{MHz}, \mathrm{CD}_{2} \mathrm{Cl}_{2}, 298 \mathrm{~K}\right): \delta 7.88(\mathrm{br}, 1 \mathrm{H}$, $\mathrm{NH}), 7.60\left(\mathrm{~d},{ }^{3} \mathrm{~J}_{\mathrm{H}-\mathrm{H}}=7.5,2 \mathrm{H}, \mathrm{CH} \mathrm{Ph}\right), 7.28\left(\mathrm{dd}^{3} J_{\mathrm{H}-\mathrm{H}}=7.5,{ }^{3} \mathrm{~J}_{\mathrm{H}-\mathrm{H}}=\right.$ $7.5,2 \mathrm{H}, \mathrm{CH} \mathrm{Ph}), 7.06\left(\mathrm{t},{ }^{3} J_{\mathrm{H}-\mathrm{H}}=7.5,1 \mathrm{H}, \mathrm{CH} \mathrm{Ph}\right), 2.90(\mathrm{~m}, 6 \mathrm{H}$, $\left.\mathrm{PCH}\left(\mathrm{CH}_{3}\right)_{2}\right), 2.39\left(\mathrm{~m}, 4 \mathrm{H}, \mathrm{CH}_{2}\right), 1.79\left(\mathrm{~m}, 4 \mathrm{H}, \mathrm{CH}_{2}\right), 1.58(\mathrm{~s}, 3 \mathrm{H}$, $\left.\mathrm{CH}_{3}\right), 1.31\left(\mathrm{dvt},{ }^{3} J_{\mathrm{H}-\mathrm{H}}=7.0, \mathrm{~N}=13.0,36 \mathrm{H}, \mathrm{PCH}\left(\mathrm{CH}_{3}\right)_{2}\right) \cdot{ }^{31} \mathrm{P}\left\{{ }^{1} \mathrm{H}\right\}$ NMR (121.4 MHz, $\left.\mathrm{CD}_{2} \mathrm{Cl}_{2}, 298 \mathrm{~K}\right): \delta 10.0(\mathrm{~s}) .{ }^{13} \mathrm{C}\left\{{ }^{1} \mathrm{H}\right\}$-APT NMR, $\mathrm{HMBC}$, and $\mathrm{HSQC}\left(75.5 \mathrm{MHz}, \mathrm{CD}_{2} \mathrm{Cl}_{2}, 298 \mathrm{~K}\right): \delta 273.9$ (s, Os=C), $171.4(\mathrm{~s}, \mathrm{C}=\mathrm{O}), 138.6$ (s, C Ph), $128.6(\mathrm{~s}, \mathrm{CH} \mathrm{Ph}), 123.6(\mathrm{~s}, \mathrm{CH} \mathrm{Ph})$, $119.6(\mathrm{~s}, \mathrm{CH} \mathrm{Ph}), 77.5\left(\mathrm{~s}, \mathrm{CH}_{2}\right), 61.9\left(\mathrm{~s}, \mathrm{CH}_{3}\right), 36.9\left(\mathrm{~s}, \mathrm{CH}_{2}\right), 26.0$ (s, $\left.\mathrm{CH}_{2}\right), 23.3$ (vt, $\left.\mathrm{N}=21.9, \mathrm{PCH}\left(\mathrm{CH}_{3}\right)_{2}\right), 22.2\left(\mathrm{~s}, \mathrm{CH}_{2}\right), 19.6$ (s, $\left.\mathrm{PCH}\left(\mathrm{CH}_{3}\right)_{2}\right)$.

Preparation of Complex 4. A brown solution of $\mathrm{OsH}_{2} \mathrm{Cl}_{2}\left(\mathrm{P}^{\mathrm{i}} \mathrm{Pr}_{3}\right)_{2}$ $(100 \mathrm{mg}, 0.171 \mathrm{mmol})$ in fluorobenzene $(6 \mathrm{~mL})$ was treated with $\mathrm{N}$-(pent-4-yn-1-yl)benzamide $(60 \mathrm{mg}, 0.342 \mathrm{mmol})$ at room temperature. The mixture was stirred for $2.5 \mathrm{~h}$. After this time, the resulting solution was evaporated to dryness. The subsequent addition of acetone to the residue afforded a purple solid that was washed with acetone $(3 \times 2 \mathrm{~mL})$ and with methanol $(3 \times 2 \mathrm{~mL})$ and dried in vacuo. Yield: $47 \mathrm{mg}(35 \%)$. Anal. Calcd. for $\mathrm{C}_{30} \mathrm{H}_{57} \mathrm{Cl}_{2} \mathrm{NOOsP}_{2}$ : C, 46.76; H, 7.45; N, 1.81. Found: C, 46.55; H, 7.62; N, 1.93. IR $\left(\mathrm{cm}^{-1}\right): \nu(\mathrm{C}=\mathrm{O}) 1637(\mathrm{~s})$, $\nu(\mathrm{NH}) 3338(\mathrm{~s}) .{ }^{1} \mathrm{H}$ NMR $\left(300 \mathrm{MHz}, \mathrm{CD}_{2} \mathrm{Cl}_{2}, 298 \mathrm{~K}\right): \delta 7.89\left(\mathrm{~d},{ }^{3} \mathrm{~J}_{\mathrm{H}-\mathrm{H}}\right.$ $=6.8,1 \mathrm{H}, \mathrm{CH} \mathrm{Ph}), 7.46(\mathrm{~m}, 4 \mathrm{H}, \mathrm{CH} \mathrm{Ph}), 6.66(\mathrm{~s}, 1 \mathrm{H}, \mathrm{NH}), 3.41(\mathrm{q}$, $\left.{ }^{3} J_{\mathrm{H}-\mathrm{H}}=6.0,2 \mathrm{H}, \mathrm{CH}_{2}\right), 2.88\left(\mathrm{~m}, 6 \mathrm{H}, \mathrm{PCH}\left(\mathrm{CH}_{3}\right)_{2}\right), 2.57\left(\mathrm{~m}, 2 \mathrm{H}, \mathrm{CH}_{2}\right)$, $2.12\left(\mathrm{~s}, 2 \mathrm{H}, \mathrm{CH}_{2}\right), 1.57\left(\mathrm{~s}, 3 \mathrm{H}, \mathrm{CH}_{3}\right), 1.30\left(\mathrm{dvt},{ }^{3} J_{\mathrm{H}-\mathrm{H}}=6.9 \mathrm{~N}=13.2\right.$, $\left.36 \mathrm{H}, \mathrm{PCH}\left(\mathrm{CH}_{3}\right)_{2}\right) \cdot{ }^{31} \mathrm{P}\left\{{ }^{\mathrm{l}} \mathrm{H}\right\} \mathrm{NMR}\left(121.4 \mathrm{MHz}, \mathrm{CD}_{2} \mathrm{Cl}_{2}, 298 \mathrm{~K}\right): \delta 8.7$ (s). ${ }^{13} \mathrm{C}\left\{{ }^{1} \mathrm{H}\right\}$-APT NMR, HMBC, and HSQC $\left(75.5 \mathrm{MHz}, \mathrm{CD}_{2} \mathrm{Cl}_{2}\right.$, $253 \mathrm{~K}): \delta 272.7\left(\mathrm{t},{ }^{2} J_{\mathrm{C}-\mathrm{P}}=4.3, \mathrm{Os}=\mathrm{C}\right), 167.2(\mathrm{~s}, \mathrm{C}=\mathrm{O}), 134.5$ (s, C Ph), 131.4 (s, CH Ph), $128.6(\mathrm{~s}, \mathrm{CH} \mathrm{Ph}), 127.2$ (s, CH Ph), 74.7 (s, $\left.\mathrm{CH}_{2}\right), 62.3\left(\mathrm{~s}, \mathrm{CH}_{3}\right), 40.4\left(\mathrm{~s}, \mathrm{CH}_{2}\right), 23.2\left(\mathrm{vt}, \mathrm{N}=22.6, \mathrm{PCH}\left(\mathrm{CH}_{3}\right)_{2}\right)$, $21.7\left(\mathrm{~s}, \mathrm{CH}_{2}\right), 19.8\left(\mathrm{~s}, \mathrm{PCH}\left(\mathrm{CH}_{3}\right)_{2}\right)$.

Preparation of Complexes 5 and 6. A purple solution of 2 (100 $\mathrm{mg}, 0.130 \mathrm{mmol})$ in dichloromethane $(6 \mathrm{~mL})$ was stirred for $48 \mathrm{~h}$ at $60^{\circ} \mathrm{C}$. After this time, the resulting solution was evaporated to dryness. The subsequent addition of diethyl ether to the residue afforded a brown solid that was washed with diethyl ether $(3 \times 2 \mathrm{~mL})$ and dried in vacuo. ${ }^{1} \mathrm{H}$ and ${ }^{31} \mathrm{P}\left\{{ }^{1} \mathrm{H}\right\}$ spectroscopy shows a 10:7 mixture of complexes 5 and 6. Yield: $30 \mathrm{mg}(29 \%)$. IR $\left(\mathrm{cm}^{-1}\right): \nu(\mathrm{C}=\mathrm{O}) 1687(\mathrm{~s}), \nu(\mathrm{NH}) 3266(\mathrm{~s})$.

Spectroscopic Data for 5 . HRMS (electrospray, $\mathrm{m} / z$ ): calcd. for $\mathrm{C}_{29} \mathrm{H}_{55} \mathrm{ClNOOsP}_{2}[\mathrm{M}-\mathrm{Cl}]^{+}, 722.3047$; found, 722.3060. ${ }^{1} \mathrm{H}$ NMR $\left(400 \mathrm{MHz}, \mathrm{CD}_{2} \mathrm{Cl}_{2}, 298 \mathrm{~K}\right): \delta 8.29(\mathrm{br}, 1 \mathrm{H}, \mathrm{NH}), 7.52\left(\mathrm{~d},{ }^{3} J_{\mathrm{H}-\mathrm{H}}=7.5\right.$, $2 \mathrm{H}, \mathrm{CH} \mathrm{Ph}), 7.31\left(\mathrm{dd},{ }^{3} J_{\mathrm{H}-\mathrm{H}}=7.5,{ }^{3} J_{\mathrm{H}-\mathrm{H}}=7.5,2 \mathrm{H}, \mathrm{CH} \mathrm{Ph}\right), 7.09(\mathrm{t}$, $\left.{ }^{3} J_{\mathrm{H}-\mathrm{H}}=7.5,1 \mathrm{H}, \mathrm{CH} \mathrm{Ph}\right), 2.70\left(\mathrm{~m}, 6 \mathrm{H}, \mathrm{PCH}\left(\mathrm{CH}_{3}\right)_{2}\right), 2.11(\mathrm{~m}, 2 \mathrm{H}$, $\left.\mathrm{CH}_{2}\right), 1.85\left(\mathrm{q},{ }^{3} \mathrm{~J}_{\mathrm{H}-\mathrm{H}}=7.8,2 \mathrm{H}, \mathrm{CH}_{2}\right), 1.42$ (overlapped, $18 \mathrm{H}$, $\mathrm{PCH}\left(\mathrm{CH}_{3}\right)_{2}$ ), 1.41 (overlapped, $2 \mathrm{H}, \mathrm{CH}_{2}$ ), 1.38 (overlapped, $18 \mathrm{H}$, $\left.\mathrm{PCH}\left(\mathrm{CH}_{3}\right)_{2}\right),-7.57\left(\mathrm{t},{ }^{2} J_{\mathrm{H}-\mathrm{P}}=16.2,1 \mathrm{H}, \mathrm{OsH}\right) .{ }^{31} \mathrm{P}\left\{{ }^{1} \mathrm{H}\right\} \mathrm{NMR}$ $\left(121.4 \mathrm{MHz}, \mathrm{CD}_{2} \mathrm{Cl}_{2}, 298 \mathrm{~K}\right): \delta 23.7(\mathrm{~s}) .{ }^{13} \mathrm{C}\left\{{ }^{1} \mathrm{H}\right\}$-APT NMR, HMBC, and HSQC $\left(100.6 \mathrm{MHz}, \mathrm{CD}_{2} \mathrm{Cl}_{2}, 298 \mathrm{~K}\right): \delta 267.1\left(\mathrm{t},{ }^{2} J_{\mathrm{C}-\mathrm{P}}=11.4\right.$, $\mathrm{Os} \equiv \mathrm{C}), 170.6(\mathrm{~s}, \mathrm{C}=\mathrm{O}), 138.9(\mathrm{~s}, \mathrm{C} \mathrm{Ph}), 129.4(\mathrm{~s}, \mathrm{CH} \mathrm{Ph}), 124.4(\mathrm{~s}$, $\mathrm{CH} \mathrm{Ph}$ ), $120.2(\mathrm{~s}, \mathrm{CH} \mathrm{Ph}), 50.6\left(\mathrm{~s}, \mathrm{CH}_{2}\right), 37.6\left(\mathrm{~s}, \mathrm{CH}_{2}\right), 26.3$ (vt, $\left.\mathrm{N}=26.2, \mathrm{PCH}\left(\mathrm{CH}_{3}\right)_{2}\right), 23.8\left(\mathrm{~s}, \mathrm{CH}_{2}\right), 20.0\left(\mathrm{~s}, \mathrm{PCH}\left(\mathrm{CH}_{3}\right)_{2}\right), 19.9(\mathrm{~s}$, $\left.\mathrm{PCH}\left(\mathrm{CH}_{3}\right)_{2}\right)$.

Spectroscopic Data for 6. HRMS: calcd. for $\mathrm{C}_{30} \mathrm{H}_{57} \mathrm{ClNOOsP}_{2}$ $[\mathrm{M}-\mathrm{Cl}]^{+}$, 736.3204; found, 736.3196. ${ }^{1} \mathrm{H}$ NMR $\left(400 \mathrm{MHz}, \mathrm{CD}_{2} \mathrm{Cl}_{2}\right.$, $298 \mathrm{~K}): \delta 8.29(\mathrm{br}, 1 \mathrm{H}, \mathrm{NH}), 7.52\left(\mathrm{~d},{ }^{3} J_{\mathrm{H}-\mathrm{H}}=7.5,2 \mathrm{H}, \mathrm{CH} \mathrm{Ph}\right), 7.31(\mathrm{dd}$, $\left.{ }^{3} J_{\mathrm{H}-\mathrm{H}}=7.5,{ }^{3} \mathrm{~J}_{\mathrm{H}-\mathrm{H}}=7.5,2 \mathrm{H}, \mathrm{CH} \mathrm{Ph}\right), 7.09\left(\mathrm{t},{ }^{3} \mathrm{~J}_{\mathrm{H}-\mathrm{H}}=7.5,1 \mathrm{H}, \mathrm{CH} \mathrm{Ph}\right)$, $2.70\left(\mathrm{~m}, 6 \mathrm{H}, \mathrm{PCH}\left(\mathrm{CH}_{3}\right)_{2}\right), 2.34\left(\mathrm{t},{ }^{3} \mathrm{H}_{\mathrm{H}-\mathrm{H}}=7.4,2 \mathrm{H}, \mathrm{CH}_{2}\right), 1.85(\mathrm{~m}, 2 \mathrm{H}$, $\left.\mathrm{CH}_{2}\right), 1.74\left(\mathrm{~s}, 3 \mathrm{H}, \mathrm{CH}_{3}\right), 1.44$ (overlapped, $\left.18 \mathrm{H}, \mathrm{PCH}\left(\mathrm{CH}_{3}\right)_{2}\right), 1.38$ (overlapped, $\left.18 \mathrm{H}, \mathrm{PCH}\left(\mathrm{CH}_{3}\right)_{2}\right), 0.99(\mathrm{~m}, 1 \mathrm{H}, \mathrm{CH}),-7.07\left(\mathrm{t},{ }^{2} J_{\mathrm{H}-\mathrm{P}}=\right.$ 16.2, $1 \mathrm{H}, \mathrm{OsH}) .{ }^{31} \mathrm{P}\left\{{ }^{1} \mathrm{H}\right\} \mathrm{NMR}\left(121.4 \mathrm{MHz}, \mathrm{CD}_{2} \mathrm{Cl}_{2}, 298 \mathrm{~K}\right): \delta 23.9$ (s). ${ }^{13} \mathrm{C}\left\{{ }^{1} \mathrm{H}\right\}$-APT NMR, HMBC, and HSQC $\left(100.6 \mathrm{MHz}, \mathrm{CD}_{2} \mathrm{Cl}_{2}, 298\right.$ $\mathrm{K}): \delta 271.8\left(\mathrm{t}^{2} J_{\mathrm{C}-\mathrm{P}}=11.4, \mathrm{Os} \equiv \mathrm{C}\right), 170.5(\mathrm{~s}, \mathrm{C}=\mathrm{O}), 139.1(\mathrm{~s}, \mathrm{C} \mathrm{Ph})$, 129.3 (s, CH Ph), 124.3 (s, CH Ph), 120.3 (s, CH Ph), 38.8 (s, CH), $37.5\left(\mathrm{~s}, \mathrm{CH}_{2}\right), 27.6$ (vt, $\left.\mathrm{N}=26.2 \mathrm{PCH}\left(\mathrm{CH}_{3}\right)_{2}\right), 23.5\left(\mathrm{~s}, \mathrm{CH}_{2}\right), 22.5$ (s, $\left.\mathrm{CH}_{3}\right), 20.0\left(\mathrm{~s}, \mathrm{PCH}\left(\mathrm{CH}_{3}\right)_{2}\right), 19.8\left(\mathrm{~s}, \mathrm{PCH}\left(\mathrm{CH}_{3}\right)_{2}\right)$.

Preparation of Complex 7. A purple solution of $4(100 \mathrm{mg}, 0.130$ $\mathrm{mmol})$ in dichloromethane $(6 \mathrm{~mL})$ was stirred for $7 \mathrm{~h}$ at room temperature. After this time, the resulting solution was evaporated to dryness. The subsequent addition of ether to the residue afforded a white solid that was washed with diethyl ether $(3 \times 2 \mathrm{~mL})$ and dried in vacuo. Yield: $34 \mathrm{mg}$ (35\%). Anal. Calcd. for $\mathrm{C}_{29} \mathrm{H}_{55} \mathrm{Cl}_{2} \mathrm{NOOsP}_{2}$ : C, 46.02; H, 7.32; N, 1.85. Found: C, 46.33; H, 7.12; N, 1.86. IR $\left(\mathrm{cm}^{-1}\right)$ : $\nu(\mathrm{C}=\mathrm{O}) 1658(\mathrm{~s}), \nu(\mathrm{NH}) 3319$ (s). ${ }^{1} \mathrm{H}$ NMR $\left(300 \mathrm{MHz}, \mathrm{CD}_{2} \mathrm{Cl}_{2}\right.$, $298 \mathrm{~K}): \delta 7.80\left(\mathrm{~d},{ }^{3} J_{\mathrm{H}-\mathrm{H}}=7.1,1 \mathrm{H}, \mathrm{CH} \mathrm{Ph}\right), 7.44(\mathrm{~m}, 4 \mathrm{H}, \mathrm{CH} \mathrm{Ph}), 6.72$ $($ br, $1 \mathrm{H}, \mathrm{NH}), 3.40\left(\mathrm{q},{ }^{3} \mathrm{~J}_{\mathrm{H}-\mathrm{H}}=7.0,2 \mathrm{H}, \mathrm{CH}_{2}\right), 2.67(\mathrm{~m}, 6 \mathrm{H}$, $\left.\mathrm{PCH}\left(\mathrm{CH}_{3}\right)_{2}\right), 2.06\left(\mathrm{~m}, 2 \mathrm{H}, \mathrm{CH}_{2}\right), 1.46\left(\mathrm{dvt},{ }^{3} \mathrm{~J}_{\mathrm{H}-\mathrm{H}}=7.2, \mathrm{~N}=13.8,18 \mathrm{H}\right.$, $\left.\operatorname{PCH}\left(\mathrm{CH}_{3}\right)_{2}\right), 1.41$ (overlapped, $\left.2 \mathrm{H}, \mathrm{CH}_{2}\right), 1.37\left(\mathrm{dvt},{ }^{3} J_{\mathrm{H}-\mathrm{H}}=7.2, \mathrm{~N}=\right.$ $\left.13.8,18 \mathrm{H}, \mathrm{PCH}\left(\mathrm{CH}_{3}\right)_{2}\right),-7.17\left(\mathrm{t},{ }^{2} J_{\mathrm{H}-\mathrm{P}}=16.8,1 \mathrm{H}, \mathrm{OsH}\right) .{ }^{31} \mathrm{P}\left\{{ }^{1} \mathrm{H}\right\}$ NMR (121.4 MHz, $\left.\mathrm{CD}_{2} \mathrm{Cl}_{2}, 298 \mathrm{~K}\right): \delta 21.4$ (s). ${ }^{13} \mathrm{C}\left\{{ }^{1} \mathrm{H}\right\}$-APT NMR, $\mathrm{HMBC}$, and HSQC $\left(75.5 \mathrm{MHz}, \mathrm{CD}_{2} \mathrm{Cl}_{2}, 298 \mathrm{~K}\right): \delta 270.5\left(\mathrm{t},{ }^{2} J_{\mathrm{C}-\mathrm{P}}=\right.$ 10.8, Os $\equiv \mathrm{C}), 167.9(\mathrm{~s}, \mathrm{C}=\mathrm{O}), 134.7$ (s, C Ph), $132.0(\mathrm{~s}, \mathrm{CH} \mathrm{Ph})$, 129.0 (s, CH Ph), 127.6 (s, CH Ph), $49.5\left(\mathrm{~s}, \mathrm{CH}_{2}\right), 39.7\left(\mathrm{~s}, \mathrm{CH}_{2}\right), 27.2$ (vt, $\left.\mathrm{N}=26.0, \mathrm{PCH}\left(\mathrm{CH}_{3}\right)_{2}\right), 23.2\left(\mathrm{~s}, \mathrm{CH}_{2}\right), 20.0\left(\mathrm{~s}, \mathrm{PCH}\left(\mathrm{CH}_{3}\right)_{2}\right)$.

Preparation of Complex 8. A purple solution of $2(100 \mathrm{mg}$, $0.130 \mathrm{mmol})$ in fluorobenzene $(6 \mathrm{~mL})$ was treated with 3-methyl-1,2butadiene $(21 \mu \mathrm{L}, 0.195 \mathrm{mmol})$ at room temperature. The mixture was stirred for $30 \mathrm{~min}$. After this time, the resulting solution was evaporated to dryness. The subsequent addition of methanol to the residue afforded a green solid that was washed with methanol $(3 \times 2 \mathrm{~mL})$ and dried in vacuo. Yield: $46 \mathrm{mg}$ (57\%). Anal. Calcd. for $\mathrm{C}_{22} \mathrm{H}_{48} \mathrm{Cl}_{2} \mathrm{OsP}_{2}$ : C, 41.57; $\mathrm{H}, 7.61$. Found: $\mathrm{C}, 41.67 ; \mathrm{H}, 7.68$. IR $\left(\mathrm{cm}^{-1}\right): \nu(\mathrm{Os}=\mathrm{C}=\mathrm{C}) 1678(\mathrm{~s})$. ${ }^{1} \mathrm{H}$ NMR $\left(300 \mathrm{MHz}, \mathrm{C}_{6} \mathrm{D}_{6}, 298 \mathrm{~K}\right): \delta 2.93\left(\mathrm{~m}, 6 \mathrm{H}, \mathrm{PCH}\left(\mathrm{CH}_{3}\right)_{2}\right), 2.40$ $\left(\mathrm{t},{ }^{5} J_{\mathrm{H}-\mathrm{P}}=2.3,6 \mathrm{H}, \mathrm{CH}_{3}\right), 1.33\left(\mathrm{dvt},{ }^{3} J_{\mathrm{H}-\mathrm{H}}=7.2, \mathrm{~N}=12.9,36 \mathrm{H}\right.$, $\left.\operatorname{PCH}\left(\mathrm{CH}_{3}\right)_{2}\right) .{ }^{31} \mathrm{P}\left\{{ }^{1} \mathrm{H}\right\}$ NMR $\left(121.4 \mathrm{MHz}, \mathrm{C}_{6} \mathrm{D}_{6}, 298 \mathrm{~K}\right): \delta-0.4(\mathrm{~s})$. ${ }^{13} \mathrm{C}\left\{{ }^{1} \mathrm{H}\right\}$-APT NMR, HMBC, and HSQC $\left(75.5 \mathrm{MHz}, \mathrm{C}_{6} \mathrm{D}_{6}, 298 \mathrm{~K}\right): \delta$ $271.1\left(\mathrm{t},{ }^{2} J_{\mathrm{C}-\mathrm{P}}=12.1, \mathrm{Os}=\mathrm{C}\right), 111.0\left(\mathrm{~s},=\mathrm{C}\left(\mathrm{CH}_{3}\right)_{2}\right), 23.6(\mathrm{vt}, \mathrm{N}=$ 23.4, $\left.\mathrm{PCH}\left(\mathrm{CH}_{3}\right)_{2}\right), 20.0\left(\mathrm{~s}, \mathrm{PCH}\left(\mathrm{CH}_{3}\right)_{2}\right), 7.6\left(\mathrm{~s}, \mathrm{CH}_{3}\right)$.

The methanol washing solutions were collected and evaporated to dryness. The residue was dissolved in diethyl ether and the solution filtered through alumina. The solvent was removed in vacuo to give a pale yellow oil. The ${ }^{1} \mathrm{H}$ and ${ }^{13} \mathrm{C}\left\{{ }^{1} \mathrm{H}\right\}$ NMR spectrum of this oil show the presence of 5-methyl- $N$-phenylhex-5-enamide.

Spectroscopic data for 5-methyl- $\mathrm{N}$-phenylhex-5-enamide are as follows. ${ }^{1} \mathrm{H}$ NMR $\left(300 \mathrm{MHz}, \mathrm{CDCl}_{3}, 298 \mathrm{~K}\right): \delta 8.21(\mathrm{br}, 1 \mathrm{H}, \mathrm{NH})$, $7.52\left(\mathrm{~d},{ }^{3} J_{\mathrm{H}-\mathrm{H}} 7.3,2 \mathrm{H}, \mathrm{CH} \mathrm{Ph}\right), 7.30(\mathrm{~m}, 2 \mathrm{H}, \mathrm{CH} \mathrm{Ph}), 7.20\left(\mathrm{t},{ }^{3} J_{\mathrm{H}-\mathrm{H}}=\right.$ 7.3, $1 \mathrm{H}, \mathrm{CH} \mathrm{Ph}), 4.76\left(\mathrm{br}, 1 \mathrm{H},=\mathrm{CH}_{2}\right), 4.71\left(\mathrm{br}, 1 \mathrm{H},=\mathrm{CH}_{2}\right), 2.34(\mathrm{t}$, $\left.{ }^{3} J_{\mathrm{H}-\mathrm{H}}=7.2,2 \mathrm{H}, \mathrm{CH}_{2}\right), 2.11\left(\mathrm{t},{ }^{3} \mathrm{~J}_{\mathrm{H}-\mathrm{H}}=7.2,2 \mathrm{H}, \mathrm{CH}_{2}\right), 1.90\left(\mathrm{q},{ }^{3} J_{\mathrm{H}-\mathrm{H}}=\right.$ 7.2, 2H, $\left.\mathrm{CH}_{2}\right), 1.73\left(\mathrm{~s}, 3 \mathrm{H}, \mathrm{CH}_{3}\right) \cdot{ }^{13} \mathrm{C}\left\{{ }^{1} \mathrm{H}\right\}$-APT NMR, HMBC, and $\operatorname{HSQC}\left(75.5 \mathrm{MHz}, \mathrm{CDCl}_{3}, 298 \mathrm{~K}\right): \delta 171.3(\mathrm{~s}, \mathrm{C}=\mathrm{O}), 145.1\left(\mathrm{~s}, \mathrm{H}_{2} \mathrm{C}=\mathrm{C}\right)$, 138.1 (s, C Ph), 129.1 (s, CH Ph), 124.3 (s, CH Ph), 119.1 (s, CH Ph), $110.9\left(\mathrm{~s}, \mathrm{H}_{2} \mathrm{C}=\mathrm{C}\right), 37.1\left(\mathrm{~s}, \mathrm{CH}_{2}\right), 37.0\left(\mathrm{~s}, \mathrm{CH}_{2}\right), 23.3\left(\mathrm{~s}, \mathrm{CH}_{2}\right)$, $22.9\left(\mathrm{~s}, \mathrm{CH}_{3}\right)$.

Preparation of Complex 9. A purple solution of $2(100 \mathrm{mg}$, $0.130 \mathrm{mmol})$ in fluorobenzene $(6 \mathrm{~mL})$ was treated with cyclohexylallene $(20 \mu \mathrm{L}, 0.130 \mathrm{mmol})$ at room temperature. The mixture was stirred for $30 \mathrm{~min}$. After this time, the resulting solution was evaporated to dryness. The subsequent addition of methanol to the residue afforded a green solid that was washed with methanol $(3 \times 2 \mathrm{~mL})$ and dried in vacuo. Yield: $39 \mathrm{mg}$ (44\%). Anal. Calcd. for $\mathrm{C}_{26} \mathrm{H}_{54} \mathrm{Cl}_{2} \mathrm{OsP}_{2}$ : C, 45.27; $\mathrm{H}, 7.89$. Found: $\mathrm{C}, 45.65 ; \mathrm{H}, 7.38 . \mathrm{IR}\left(\mathrm{cm}^{-1}\right): \nu(\mathrm{Os}=\mathrm{C}=\mathrm{C}) 1655(\mathrm{~s}) .{ }^{1} \mathrm{H}$ NMR $\left(300 \mathrm{MHz}, \mathrm{C}_{6} \mathrm{D}_{6}, 298 \mathrm{~K}\right): \delta 3.09\left(\mathrm{~m}, 6 \mathrm{H}, \mathrm{PCH}\left(\mathrm{CH}_{3}\right)_{2}\right), 2.62(\mathrm{~m}, \mathrm{H}, \mathrm{CH}$ $\mathrm{Cy}), 1.91\left(\mathrm{~m}, 2 \mathrm{H}, \mathrm{CH}_{2}\right), 1.71\left(\mathrm{~m}, 2 \mathrm{H}, \mathrm{CH}_{2}\right) 1.57\left(\mathrm{~m}, 2 \mathrm{H}, \mathrm{CH}_{2}\right), 1.36$ (overlapped with the $\mathrm{CH}_{3}$ of $\mathrm{P}^{\mathrm{i}} \mathrm{Pr}_{3}$ assigned indirectly by $\mathrm{HSQC}, 4 \mathrm{H}$, $\mathrm{CH}_{2}$ ), 1.36 (overlapped with the $\mathrm{CH}_{3}$ of $\mathrm{P}^{\mathrm{i}} \mathrm{Pr}_{3}$ assigned indirectly by $\mathrm{HSQC},=\mathrm{CH}), 1.36\left(\mathrm{dvt},{ }^{3} \mathrm{~J}_{\mathrm{H}-\mathrm{H}}=6.6, \mathrm{~N}=12.9,36 \mathrm{H}, \mathrm{PCH}\left(\mathrm{CH}_{3}\right)_{2}\right)$. ${ }^{31} \mathrm{P}\left\{{ }^{1} \mathrm{H}\right\}$ NMR (121.4 MHz, $\left.\mathrm{C}_{6} \mathrm{D}_{6}, 298 \mathrm{~K}\right): \delta 2.5(\mathrm{~s}) .{ }^{13} \mathrm{C}\left\{{ }^{1} \mathrm{H}\right\}$-APT $\mathrm{NMR}, \mathrm{HMBC}$, and HSQC $\left(75.5 \mathrm{MHz}, \mathrm{C}_{6} \mathrm{D}_{6}, 298 \mathrm{~K}\right): \delta 270.9\left(\mathrm{t},{ }^{2} J_{\mathrm{C}-\mathrm{P}}=\right.$ 10.2 , Os= $)$ ), $111.2\left(\mathrm{t}^{3} \mathrm{~J}_{\mathrm{C}-\mathrm{p}}=4.4,=\mathrm{CH}\right), 37.8\left(\mathrm{~s}, \mathrm{CH}_{2}\right), 28.5(\mathrm{~s}, \mathrm{CH})$, $26.7\left(\mathrm{~s}, \mathrm{CH}_{2}\right), 26.3\left(\mathrm{~s}, \mathrm{CH}_{2}\right), 23.3\left(\mathrm{vt}, \mathrm{N}=23.1, \mathrm{PCH}\left(\mathrm{CH}_{3}\right)_{2}\right), 19.7$ (s, $\left.\operatorname{PCH}\left(\mathrm{CH}_{3}\right)_{2}\right)$.

The methanol washing solutions were collected and evaporated to dryness. The residue was dissolved in ether and the solution filtered 
through alumina. The solvent was removed in vacuo to give a pale yellow oil. The ${ }^{1} \mathrm{H}$ and ${ }^{13} \mathrm{C}\left\{{ }^{1} \mathrm{H}\right\}$ NMR spectra of this oil show the presence of the major compound 5-methyl- $N$-phenylhex-5-enamide.

Structural Analysis of Complexes 2, 5, 7, and 8. X-ray data were collected for the complexes on a Bruker Smart APEX CCD (2) or APEX CCD DUO (5, 7 and 8) diffractometer equipped with a normal-focus, $2.4 \mathrm{~kW}$ sealed-tube source (Mo radiation, $\lambda=0.71073 \AA$ ) operating at $50 \mathrm{kV}$ and $40 \mathrm{~mA}(5)$ or $30 \mathrm{~mA}(2,7$, and 8$)$. Data were collected over the complete sphere. Each frame exposure time was $10 \mathrm{~s}(\mathbf{5}, 7$, and $\mathbf{8})$ or $30 \mathrm{~s}(2)$ covering $0.3^{\circ}$ in $\omega$. Data were corrected for absorption by using a multiscan method applied with the SADABS program. ${ }^{37}$ The structures were solved by Patterson or direct methods and refined by full-matrix least squares on $F^{2}$ with SHELXL97, ${ }^{38}$ including isotropic and subsequently anisotropic displacement parameters. The hydrogen atoms (except hydrides) were observed in the least-squares Fourier maps or calculated and refined freely or using a restricted riding model. Hydrogens bonded to metal atoms were observed in the last cycles of refinement but refined too close to metals; therefore, a restricted refinement model was used for all of them $(d(\mathrm{Os}-\mathrm{H}=1.59(1) \AA) .5$ and 7 crystallizes with two molecules of $\mathrm{CH}_{2} \mathrm{Cl}_{2}$.

Crystal data for 2: $\mathrm{C}_{30} \mathrm{H}_{57} \mathrm{Cl}_{2} \mathrm{NOOsP}_{2}, \mathrm{M}_{\mathrm{w}}$ 770.81, purple, irregular block $(0.30 \times 0.04 \times 0.01)$, orthorhombic, space group Fdd2, $a=$ 26.2990(19) $\AA$, $b=57.306(4) \AA, c=9.0152(7) \AA, V=13586.7(18) \AA^{3}$, $Z=16, Z^{\prime}=1, D_{\text {calc }}=1.507 \mathrm{~g} \mathrm{~cm}^{-3}, F(000)=6272, T=100(2) \mathrm{K}, \mu=$ $4.028 \mathrm{~mm}^{-1}$; 32394 measured reflections $\left(2 \theta=3-58^{\circ}, \omega\right.$ scans $\left.0.3^{\circ}\right)$, 7785 unique reflections $\left(R_{\text {int }}=0.0685\right)$; minimum $/$ maximum transmission factors 0.347/0.492; final agreement factors $R 1=0.0375$ (6964 observed reflections, $I>2 \sigma(I))$ and $w \mathrm{R} 2=0.0750$; refined Flack parameter $0.252(7) ; 7785 / 1 / 351 \mathrm{data} /$ restraints/parameters; $\mathrm{GOF}=1.050$; largest peak and hole 2.866 (close to osmium atom) and $-1.363 \mathrm{e} / \AA^{3}$.

Crystal data for 5: $\mathrm{C}_{29} \mathrm{H}_{55} \mathrm{Cl}_{2} \mathrm{NOOsP}_{2} \cdot 2 \mathrm{CH}_{2} \mathrm{Cl}_{2}, \mathrm{M}_{\mathrm{w}}$ 926.63, colorless, irregular block $(0.11 \times 0.06 \times 0.02)$, triclinic, space group $P \overline{1}, a=8.849(2) \AA, b=12.110(3) \AA, c=19.188(5) \AA, \alpha=93.888(4)^{\circ}$, $\beta=92.002(4)^{\circ}, \gamma=105.872(4)^{\circ}, V=1970.1(8) \AA^{3}, Z=2, Z^{\prime}=1, D_{\text {calc }}=$ $1.562 \mathrm{~g} \mathrm{~cm}^{-3}, F(000)=936, T=153(2) \mathrm{K}, \mu=3.749 \mathrm{~mm}^{-1} ; 18798$ measured reflections $\left(2 \theta=3-58^{\circ}, \omega\right.$ scans $\left.0.3^{\circ}\right), 7991$ unique reflections $\left(R_{\mathrm{int}}=0.0523\right)$; minimum $/$ maximum transmission factors $0.651 / 0.862$; final agreement factors $\mathrm{R} 1=0.0395$ (6413 observed reflections, $I>2 \sigma(I))$ and $\mathrm{wR} 2=0.0754 ; 7991 / 1 / 403$ data/restraints/ parameters; $\mathrm{GOF}=1.000$; largest peak and hole 0.756 (close to osmium atoms) and $-0.630 \mathrm{e} / \AA^{3}$.

Crystal data for 7: $\mathrm{C}_{29} \mathrm{H}_{55} \mathrm{Cl}_{2} \mathrm{NOOsP}_{2} \cdot 2 \mathrm{CH}_{2} \mathrm{Cl}_{2}, \mathrm{M}_{\mathrm{w}}$ 926.63, colorless, irregular block $(0.09 \times 0.08 \times 0.05)$, monoclinic, space group $P 2_{1} / n, a=15.774(4) \AA, b=13.012(3) \AA, c=20.173(5) \AA$, $\beta=105.651(4)^{\circ}, V=3987.0(17) \AA^{3}, Z=4, Z^{\prime}=1, D_{\text {calc }}=1.544 \mathrm{~g} \mathrm{~cm}^{-3}$, $F(000)=1872, T=100(2) \mathrm{K}, \mu=3.705 \mathrm{~mm}^{-1} ; 36954$ measured reflections $\left(2 \theta=3-57^{\circ}, \omega\right.$ scans $\left.0.3^{\circ}\right), 10352$ unique reflections $\left(R_{\text {int }}=\right.$ 0.0607); minimum/maximum transmission factors $0.736 / 0.862$; final agreement factors R1 $=0.0356$ (7741 observed reflections, $I>2 \sigma(I)$ ) and $\mathrm{wR}_{2}=0.0719 ; 10352 / 1 / 397 \mathrm{data} /$ restraints $/$ parameters; $\mathrm{GOF}=0.997$; largest peak and hole 1.060 (close to osmium atoms) and $-1.109 \mathrm{e} / \AA^{3}$.

Crystal data for 8: $\mathrm{C}_{22} \mathrm{H}_{48} \mathrm{Cl}_{2} \mathrm{OsP}_{2}, \mathrm{M}_{\mathrm{w}}$ 635.64, green, irregular block $(0.16 \times 0.11 \times 0.08)$, monoclinic, space group $C 2 / c, a=21.184(3) \AA$, $b=9.6719(13) \AA, c=16.227(2) \AA, \beta: 125.504(2)^{\circ}, V=2706.6(6) \AA^{3}$, $Z=4, Z^{\prime}=0.5, D_{\text {calc }}: 1.560 \mathrm{~g} \mathrm{~cm}^{-3}, \mathrm{~F}(000): 1280, \mathrm{~T}=100(2) \mathrm{K}, \mu$ $5.034 \mathrm{~mm}^{-1} .13794$ measured reflections $\left(2 \theta=3-58^{\circ}, \omega\right.$ scans $\left.0.3^{\circ}\right)$, 3544 unique reflections $\left(R_{\text {int }}=0.0340\right)$; minimum $/$ maximum transmission factors $0.711 / 0.862$; final agreement factors $\mathrm{R} 1=0.0213(3345$ observed reflections, $I>2 \sigma(I))$ and $\mathrm{wR} 2=0.0484 ; 3544 / 0 / 131$ data/ restraints/parameters; GOF = 1.039; largest peak and hole 1.788 and $-1.465 \mathrm{e} / \AA^{3}$.

\section{ASSOCIATED CONTENT}

\section{(S Supporting Information}

The Supporting Information is available free of charge on the ACS Publications website at DOI: 10.1021/acs.organomet.5b00777.
Positional and displacement parameters, crystallographic data, and bond lengths and angles of compounds 2, 5, 7, and 8 (CIF)

${ }^{1} \mathrm{H}$ and ${ }^{13} \mathrm{C}\left\{{ }^{1} \mathrm{H}\right\}$-APT NMR spectra of complexes 2-9 and ${ }^{1} \mathrm{H}-{ }^{13} \mathrm{C}$ HMBC and ${ }^{1} \mathrm{H}-{ }^{13} \mathrm{C}$ HSQC NMR spectra of complexes 6 and 7 (PDF)

\section{AUTHOR INFORMATION}

\section{Corresponding Authors}

*E-mail for M.A.E.: maester@unizar.es.

*E-mail for J.L.M.: joseluis.mascarenas@usc.es.

\section{Notes}

The authors declare no competing financial interest.

\section{ACKNOWLEDGMENTS}

Financial support from the Spanish MINECO (Projects CTQ2014-52799-P, SAF2013-41943-R, and CTQ2014-51912REDC), the DGA (E35), the ERDF, the European Research Council (Advanced Grant No. 340055) and the European Social Fund (FSE), and the Xunta de Galicia (grants GRC2013-041, EM2013/036, 2015-CP082 and a Parga Pondal contract to M.G.) is acknowledged.

\section{REFERENCES}

(1) (a) Grubbs, R. H.; Miller, S. J.; Fu, G. C. Acc. Chem. Res. 1995, 28, 446-452. (b) Grubbs, R. H.; Chang, S. Tetrahedron 1998, 54, 44134450. (c) Trnka, T. M.; Grubbs, R. H. Acc. Chem. Res. 2001, 34, 18-29. (d) Grubbs, R. H. Tetrahedron 2004, 60, 7117-7140. (e) Bielawski, C. W.; Grubbs, R. H. Prog. Polym. Sci. 2007, 32, 1-29. (f) Vougioukalakis, G. C.; Grubbs, R. H. Chem. Rev. 2010, 110, 1746-1787. (g) Herbert, M. B.; Grubbs, R. H. Angew. Chem., Int. Ed. 2015, 54, 5018-5024.

(2) (a) Nguyen, S. T.; Johnson, L. K.; Grubbs, R. H.; Ziller, J. W. J. Am. Chem. Soc. 1992, 114, 3974-3975. (b) Nguyen, S. T.; Grubbs, R. H.; Ziller, J. W. J. Am. Chem. Soc. 1993, 115, 9858-9859.

(3) (a) Schwab, P.; France, M. B.; Ziller, J. W.; Grubbs, R. H. Angew. Chem., Int. Ed. Engl. 1995, 34, 2039-2041. (b) Schwab, P.; Grubbs, R. H.; Ziller, J. W. J. Am. Chem. Soc. 1996, 118, 100-110.

(4) Espuelas, J.; Esteruelas, M. A.; Lahoz, F. J.; Oro, L. A.; Ruiz, N. J. Am. Chem. Soc. 1993, 115, 4683-4689.

(5) Spivak, G. J.; Coalter, J. N.; Oliván, M.; Eisenstein, O.; Caulton, K. G. Organometallics 1998, 17, 999-1001.

(6) (a) Collado, A.; Esteruelas, M. A.; López, F.; Mascareñas, J. L.; Oñate, E.; Trillo, B. Organometallics 2010, 29, 4966-4974. (b) Collado, A.; Esteruelas, M. A.; Oñate, E. Organometallics 2011, 30, 1930-1941. (c) Collado, A.; Esteruelas, M. A.; Gulías, M.; Mascareñas, J. L.; Oñate, E. Organometallics 2012, 31, 4450-4458.

(7) (a) Werner, H.; Jung, S.; Weberndörfer, B.; Wolf, J. Eur. J. Inorg. Chem. 1999, 1999, 951-957. (b) Buil, M. L.; Eisenstein, O.; Esteruelas, M. A.; García-Yebra, C.; Gutiérrez-Puebla, E.; Oliván, M.; Oñate, E.; Ruiz, N.; Tajada, M. A. Organometallics 1999, 18, 4949-4959. (c) Buil, M. L.; Esteruelas, M. A.; García-Yebra, C.; Gutiérrez-Puebla, E.; Oliván, M. Organometallics 2000, 19, 2184-2193. (d) Barrio, P.; Esteruelas, M. A.; Oñate, E. Organometallics 2002, 21, 2491-2503. (e) Jia, G. Coord. Chem. Rev. 2007, 251, 2167-2187. (f) Castro-Rodrigo, R.; Esteruelas, M. A.; López, A. M.; Oñate, E. Organometallics 2008, 27, 3547-3555.

(8) See for example: (a) Mayr, A.; Asaro, M. F.; Kjelsberg, M. A.; Lee, K. S.; Van Engen, D. Organometallics 1987, 6, 432-434. (b) Doyle, R. A.; Angelici, R. J. Organometallics 1989, 8, 2207-2214. (c) Garrett, K. E.; Sheridan, J. B.; Pourreau, D. B.; Feng, W. C.; Geoffroy, G. L.; Staley, D. L.; Rheingold, A. L. J. Am. Chem. Soc. 1989, 111, 8383-8391. (d) Blosch, L. L.; Abboud, K.; Boncella, J. M. J. Am. Chem. Soc. 1991, 113, 70667068. (e) Bastos, C. M.; Daubenspeck, N.; Mayr, A. Angew. Chem., Int. Ed. Engl. 1993, 32, 743-745. (f) Giannini, L.; Solari, E.; Floriani, C.; Chiesi-Villa, A.; Rizzoli, C. J. Am. Chem. Soc. 1998, 120, 823-824. (g) Esteruelas, M. A.; López, A. M.; Oliván, M. Coord. Chem. Rev. 2007, 251, 795-840. (h) Bolaño, T.; Castarlenas, R.; Esteruelas, M. A.; Oñate, 
E. Organometallics 2007, 26, 2037-2041. (i) Bolaño, T.; Castarlenas, R.; Esteruelas, M. A.; Oñate, E. J. Am. Chem. Soc. 2007, 129, 8850-8859. (j) Buil, M. L.; Esteruelas, M. A.; Garcés, K.; Oñate, E. Organometallics 2009, 28, 5691-5696. (k) Boone, M. P.; Brown, C. C.; Ancelet, T. A.; Stephan, D. W. Organometallics 2010, 29, 4369-4374.

(9) (a) Esteruelas, M. A.; González, A. I.; López, A. M.; Oñate, E. Organometallics 2003, 22, 414-425. (b) Esteruelas, M. A.; González, A. I.; López, A. M.; Oñate, E. Organometallics 2004, 23, 4858-4870. (c) Castarlenas, R.; Esteruelas, M. A.; Oñate, E. Organometallics 2007, 26, 2129-2132. (d) Buil, M. L.; Esteruelas, M. A.; Garcés, K.; Oliván, M.; Oñate, E. Organometallics 2008, 27, 4680-4690.

(10) Ozerov, O. V.; Watson, L. A.; Pink, M.; Caulton, K. G. J. Am. Chem. Soc. 2007, 129, 6003-6016.

(11) (a) Bolaño, T.; Castarlenas, R.; Esteruelas, M. A.; Modrego, F. J.; Oñate, E. J. Am. Chem. Soc. 2005, 127, 11184-11195. (b) Bolaño, T.; Esteruelas, M. A.; Oñate, E. J. Organomet. Chem. 2011, 696, 3911-3923.

(12) Esteruelas, M. A.; Lahoz, F. J.; Oñate, E.; Oro, L. A.; Valero, C.;

Zeier, B. J. Am. Chem. Soc. 1995, 117, 7935-7942.

(13) Chen, J.; Shi, C.; Sung, H. H. Y.; Williams, I. D.; Lin, Z.; Jia, G. Angew. Chem., Int. Ed. 2011, 50, 7295-7299.

(14) (a) Grubbs, R. H.; Schwab, P.; Nguyen, S. T. United States Patent US 7,102,047B2, Sept 5, 2006. (b) Grubbs, R. H.; Schwab, P.; Nguyen, S. T. United States Patent US 8,604,141 B2, Dec 6, 2013.

(15) Chen, X.; Engle, K. M.; Wang, D.-H.; Yu, J.-Q. Angew. Chem., Int. Ed. 2009, 48, 5094-5115.

(16) Tang, R.-Y.; Li, G.; Yu, J.-Q. Nature 2014, 507, 215-220.

(17) (a) Brumaghim, J. L.; Girolami, G. S. Chem. Commun. 1999, 953954. (b) Werner, H.; Stüer, W.; Wolf, J.; Laubender, M.; Weberndörfer, B.; Herbst-Irmer, R; Lehmann, C. Eur. J. Inorg. Chem. 1999, 1999, 1889-1897. (c) Castarlenas, R.; Esteruelas, M. A.; Oñate, E. Organometallics 2001, 20, 2294-2302. (d) Gusev, D. G.; Lough, A. J. Organometallics 2002, 21, 2601-2603. (e) Esteruelas, M. A.; FernándezAlvarez, F. J.; Oliván, M.; Oñate, E. J. Am. Chem. Soc. 2006, 128, 45964597. (f) Castarlenas, R.; Esteruelas, M. A.; Oñate, E. Organometallics 2007, 26, 3082-3084. (g) Castro-Rodrigo, R.; Esteruelas, M. A.; López, A. M.; Oñate, E. Organometallics 2008, 27, 3547-3555.

(18) Barrio, P.; Esteruelas, M. A.; Lledós, A.; Oñate, E.; Tomás, J. Organometallics 2004, 23, 3008-3015.

(19) Bourgault, M.; Castillo, A.; Esteruelas, M. A.; Oñate, E.; Ruiz, N. Organometallics 1997, 16, 636-645.

(20) The insertion of an alkylidene group into a $\mathrm{M}-\mathrm{H}$ bond, the reserve reaction, is a well-known process. See for example: (a) Cooke, J.; Cullen, W. R.; Green, M.; Stone, F. G. A. J. Chem. Soc. A 1969, 18721874. (b) Herrmann, W. A. Angew. Chem., Int. Ed. Engl. 1978, 17, 800812. (c) Putala, M.; Lemenovskii, D. A. Russ. Chem. Rev. 1994, 63, 197216.

(21) The methylidene group is probably trapped by the solvent, since the formation of ethylene is not observed. See for example: Urbano, J.; Braga, A. A. C.; Maseras, F.; Álvarez, E.; Díaz-Requejo, M. M.; Pérez, P.J. Organometallics 2009, 28, 5968-5981. All attempts to trap the methylidene with an olefin were unsuccessful. Complex mixtures were formed as a consequence of competitive processes, including olefin metathesis.

(22) There are precedents for this migration. See for example: Allen, S. R.; Beevor, R. G.; Green, M.; Orpen, A. G.; Paddick, K. E.; Williams, I. D. J. Chem. Soc., Dalton Trans. 1987, 591-604.

(23) (a) Wen, T. B.; Yang, S.-Y.; Zhou, Z. Y.; Lin, Z.; Lau, C.-P.; Jia, G. Organometallics 2000, 19, 3757-3761. (b) Wen, T. B.; Zhou, Z. Y.; Lo, M. F.; Williams, I. D.; Jia, G. Organometallics 2003, 22, 5217-5225. (c) Wen, T. B.; Hung, W. Y.; Zhou, Z. Y.; Lo, M. F.; Williams, I. D.; Jia, G. Eur. J. Inorg. Chem. 2004, 2004, 2837-2846.

(24) (a) Rybtchinski, B.; Milstein, D. Angew. Chem., Int. Ed. 1999, 38 , 870-883. (b) Perthuisot, C.; Edelbach, B. L.; Zubris, D. L.; Simhai, N.; Iverson, C. N.; Müller, C.; Satoh, T.; Jones, W. D. J. Mol. Catal. A: Chem. 2002, 189, 157-168. (c) Jun, C.-H. Chem. Soc. Rev. 2004, 33, 610-618.

(25) See for example: (a) Strutz, H.; Schrock, R. R. Organometallics 1984, 3, 1600-1601. (b) Schrock, R. R. Polyhedron 1995, 14, 31773195. (c) Chisholm, M. H.; Davidson, E. R.; Quinlan, K. B. J. Am. Chem. Soc. 2002, 124, 15351-15358.
(26) Bianchini, C.; Casares, J. A.; Peruzzini, M.; Romerosa, A.; Zanobini, F. J. Am. Chem. Soc. 1996, 118, 4585-4594.

(27) Datta, S.; Chang, C.-L.; Yeh, K.-L.; Liu, R.-S. J. Am. Chem. Soc. 2003, 125, 9294-9295.

(28) Lynam, J. M. Chem. - Eur. J. 2010, 16, 8238-8247.

(29) See for example: (a) Venkatesan, K.; Blacque, O.; Fox, T.; Alfonso, M.; Schmalle, H. W.; Kheradmandan, S.; Berke, H. Organometallics 2005, 24, 920-932. (b) Ilg, K.; Paneque, M.; Poveda, M. L.; Rendón, N.; Santos, L. L.; Carmona, E.; Mereiter, K. Organometallics 2006, 25, 2230-2236. (c) de los Rios, I.; Bustelo, E.; Puerta, M. C.; Valerga, P. Organometallics 2010, 29, 1740-1749.

(30) (a) Buil, M. L.; Esteruelas, M. A.; Garcés, K.; Oñate, E. J. Am. Chem. Soc. 2011, 133, 2250-2263. (b) Esteruelas, M. A.; López, A. M.; Mora, M.; Oñate, E. Organometallics 2012, 31, 2965-2970.

(31) Liu, C.-W.; Lin, Y.-C.; Huang, S.-L.; Cheng, C.-W.; Liu, Y.-H.; Wang, Y. Organometallics 2007, 26, 3431-3439.

(32) Ikeda, Y.; Yamaguchi, T.; Kanao, K.; Kimura, K.; Kamimura, S.; Mutoh, Y.; Tanabe, Y.; Ishii, Y. J. Am. Chem. Soc. 2008, 130, 1685616857.

(33) Batuecas, M.; Escalante, L.; Esteruelas, M. A.; García-Yebra, C.; Oñate, E.; Saa, C. Angew. Chem., Int. Ed. 2011, 50, 9712-9715.

(34) Baya, M.; Buil, M. L.; Esteruelas, M. A.; López, A. M.; Oñate, E.; Rodríguez, J. R. Organometallics 2002, 21, 1841-1848.

(35) (a) Castarlenas, R.; Esteruelas, M. A.; Gutierrez-Puebla, E.; Oñate, E. Organometallics 2001, 20, 1545-1554. (b) Castarlenas, R.; Esteruelas, M. A.; Lalrempuia, R.; Oliván, M.; Oñate, E. Organometallics 2008, 27, 795-798. (c) Castro-Rodrigo, R.; Esteruelas, M. A.; López, A. M.; López, F.; Mascareñas, J. L.; Oliván, M.; Oñate, E.; Saya, L.; Villarino, L. J. Am. Chem. Soc. 2010, 132, 454-455. (d) Castro-Rodrigo, R; Esteruelas, M. A.; López, A. M.; Mozo, S.; Oñate, E. Organometallics 2010, 29, 4071-4079.

(36) (a) Aracama, M.; Esteruelas, M. A.; Lahoz, F. J.; López, J. L.; Meyer, U.; Oro, L. A.; Werner, H. Inorg. Chem. 1991, 30, 288-293. (b) Conti, P.; Tamborini, L.; Pinto, A.; Sola, L.; Ettari, R.; Mercurio, C.; De Micheli, C. Eur. J. Med. Chem. 2010, 45, 4331-4338. (c) Quiñones, N.; Seoane, A.; García-Fandiño, R.; Mascareñas, J. L.; Gulías, M. Chem. Sci. 2013, 4, 2874-2879.

(37) Blessing, R. H. Acta Crystallogr., Sect. A: Found. Crystallogr. 1995, 51, 33-38. SADABS: Area-detector absorption correction; Bruker-AXS, Madison, WI, 1996

(38) SHELXTL Package v. 6.14; Bruker-AXS, Madison, WI, 2000. Sheldrick, G. M. Acta Crystallogr., Sect. A: Found. Crystallogr. 2008, 64, $112-122$. 